\title{
Fatih-Gennaidus Tartışmasının Ürettiği, Konjonktürel Bir Hıristiyanlık Eleştirisi
}

\author{
A Conjunctural Criticism of Christianity, Resulting from Discussions between \\ Mehmed II and Gennadios II Scholarios
}

\section{Fuat Aydın ${ }^{*}$}

Öz

Osmanlı devleti kendisinden önceki İslam devletlerinin geleneklerini, kendisine özgü ilaveler ekleyerek devam ettirmiştir. Bu geleneklerden biri de Yahudilik ve Hıristiyanlığa yönelik dini tartş̧maları/eleştirileri içeren reddiye geleneğidir. Kaynaklarda, Osmanlı devletinin başlangıcından Fatih'in İstanbul'u fethine kadar Gregory Palamas ve Manuel II Palelogos'la Müslümanların yaptıkları iki dini tartşsma zikredilir. 1454/55'te, Fatih'in İstanbul'u fethinden iki yıla yakın bir süre sonra yazıldığı kesin ve makaleye konu olan metin (Risâle), Osmanlı dönemindeki, daha sonra sayıları artacak olan Hıristiyanlık karşıt ilk reddiyedir. David Thomas Risâle'nin ismi olarak Hücecü'l-milleti'l-Hanifiyye ve cevâbu kulli suâl olarak zikretse de metinde ne yazılma sebebi ne de kendisinin ve yazarının ismine dair bir bilgi verilir. Risâle'nin içeriğinden, Hıristiyanlık eleştirisi üzerinden doğrudan bir İslam savunusu olduğu anlaşılmaktadır. Fatih'in patrik II. Gennadius Scholaris ile dini müzakereler yaptığı ve ondan Ortodoks inancını özet olarak anlatan bir metin yazması bağlamında kaleme alınmıştır. Gennadius'un metninin "İnsanlığın Kurtuluşuna Dair Yegâne Yol” şeklindeki başlığı ve içinde yer verdiği Ortodoks inanç esasları, İslam'ın iddialarına ve Hıristiyanlığa yönelik eleştirilerine bir meydan okuma içerir. Bu yüzden, Risâle'nin bu tür meydan okumalara cevaben Fatih tarafindan yazdırıldığı söylenebilir. Zâhidî’nin er-Risâlütü'n-Nâsıriyye esas alınarak oluşturulmuş olan Risâle üç bölümde oluşur. Birinci bölüm, sultanın huzurundaki dini tartş̧manın nasıl olacağı ve Hıristiyanların sordukları sorulara yönelik cevaplara ayrılmıştır. İkinci bölüm, Hz. Peygamber'in mucizelerini içerir. Üçüncü bölüm ise, onun peygamberliğine karşı çıkanları ele alır.

\section{Anahtar Kelimeler}

Fâtih, Gennadius, Reddiye, Osmanlı, Zâhidî, İtikatnâme, Mehmed II, Gennadius II Scholaris, Raddiya, Ottomon, Az-Zâhidī, Itikâtnâmah

\begin{abstract}
The Ottoman state continued the traditions of previous Islamic states with its own specific additions. One of these was the tradition of refutation, which included religious criticisms of Judaism and Christianity. The historical sources mention two religious disputes that Ottoman Muslims had with Gregory Palamas and Manuel II Paleilogos from the beginning of the Ottoman state to the conquest of Istanbul by Mehmed II. Risālah, which is fairly certain to have been written one or two years after Mehmed II's conquest of Istanbul (1454/55) and which is the subject of this article, is the first antiChristian refutation of the Ottoman period. The numbers of such refutations will increase later. David Thomas mentions the name of the Risālah as Hücecüll-milleti'l-Hanifiyye wa cevābu kulli suāl. However, It provides no information about the reason for writing in the text or the name of the text itself or the author. It is understood from the contents of the Risālah that it is a direct defense of Islam through a criticism of Christianity. The conqueror Mehmed II had several religious talks with the Patriarch II. Gennadios Scholarios. The text in question was written upon a request for Gennadios
\end{abstract}

* Sorumlu Yazar: Fuat Aydın (Prof. Dr.), Sakarya Üniversitesi, Illahiyat Fakültesi, Felsefe Din Bilimleri Bölümü, Sakarya, Türkiye. E-posta: faydin@sakarya.edu.tr ORCID: 0000-0001-5779-7741

Atıf: Aydin, Fuat. “Fatih-Gennaidus Tartışmasının Ürettiği, Konjonktürel Bir Hıristiyanlık Eleştirisi.” darulfunun ilahiyat 32, 2 (2021): $355-385$. https://doi.org/10.26650/di.2021.32.2.1015569 
to write a text that would summarize the Orthodox faith. The title of Gennadios' text as "The Only Way to the Salvation of Humanity" and the orthodox belief principles it sets forth contain a direct challenge to the claims of Islam as the last religion and its criticisms of Christianity. Therefore, it can be said that the Risālah was request to write by Fatih in response to these challenges. The Risālah, which was composed based on Zāhidī's er-Risālatü'n-Nāsıriyyah, consists of three parts. The first section is devoted to how the religious debate in the presence of the sultan would be conducted and answered to the questions asked by the Christians. The second part contains the miracles of Muhammad. (p.b.u). The third section deals with those who oppose his prophethood.

\section{Keywords}

Ottoman, Gennadios Scholarios, Mehmed II, İtikâdnâme, Criticism of Christianity

\section{Extended Summary}

The Ottoman state continued the traditions of previous Islamic states by adding its own specific traditions. One of these is the tradition of refutation (raddiyah), which included criticisms and religious debates against Judaism and Christianity. Islam identifies itself as the continuation of Judaism and Christianity to legitimize itself. We have information about the existence of religious disputes between Ottoman Muslims and Christians (Gregory Palamas - the ulema of the Bursa and Iznik, and Manuel II. PaleologosHac1 Bayram Veli) from the beginning of the Ottoman state to the conquest of Istanbul by Mehmed II (the Conqueror). However, we do not have any information about the existence of any refutations written by the Ottomans in that period. Therefore, Risālah, which is the subject of this article and which is relatively certain to have been written in 1454/55, approximately two years after Fatih's conquest of Istanbul, is the first example of this literature. In the text, neither the reason for writing the refutation nor the name of Risālah or the author is given. These are not mentioned in any other contemporary biographical books either.

It is understood from the contents of the Risālah that it is a defense of Islam against Christian claims rather than a direct criticism of Christianity, indicating that it was written in response to such a criticism of Islam. However, in an environment where Mehmed II (the Conqueror) put an end to Byzantium and called himself the emperor of the east and west, such an open criticism does not seem very likely. However, religious discussions were held between Mehmed II (the Conqueror) and Gennadios II Scholarios, whom he appointed as first patriarch of Muslim Istanbul. We know that Mehmed asked Gennadios to write a text that summarized the Orthodox faith, which text we have today. When one considers the title of the text of Gennadios, generally known as the Confession (Itikatnāmah), as "The Only Way to the Salvation of Humanity" and its explanations about the Christian faith, it will be seen that it contains implicit challenges to the claims of Islam. Therefore, as a reasonable conclusion, we believe that the Risâlah was requested to write by Mehmed II as a response to the secret challenge contained in these religious negotiations and Gennadios's text. We have two manuscripts of Risālah. The first and the 
oldest manuscript was found at the French National Library. The second manuscript dates to the seventeenth century $(1657 \mathrm{CE})$ and was found at the Library of Leiden University. Neither of them is based on an author copy. The French manuscript may have been used as a source for the Leiden manuscript or both of them may have used another manuscript that we do not have.

The Risālah consists of three parts. The first part is devoted to demonstrating how the religious discussion in the presence of the sultan would take place. In addition, It provides how the answers to give for the questions asked by Christians. According to the title, this chapter treats two themes. One of them is the methodology concerning the MuslimChristian religious discussion in the presence of the sultan. Second, the author sets forth questions that Christians ask about Islam. He divides those questions into those that are scientific and those that are popular. He then communicates the questions and offers the answers given by Muslims.

The second part contains the miracles of the Prophet. In this chapter, the author mentions, as a first topic, Christian suspicions about the miracles of Muhammad and then analyzes those suspicions to demonstrate their invalidity. According to the author, the miracles of Muhammad are properly divided into two groups. The first group is preprophetic miracles that prepare Muhammad for his prophethood and are named as Irhāsi The second group consists of Tasdīki miracles that demonstrate the claim of prophethood by Muhammad as true.

The third chapter deals with those who oppose His prophethood. In this chapter, the author discusses those who do not accept the prophethood and divides them into two groups. The first group argues that there is no need for the prophethood. According to the second group, Muhammad was not sent to all human and non-human beings. The two groups together comprise 10 sub-groups.

The main source of the Risālah is Zāhidī's ar-Risālatu'n-Nāṣıriyyah. Zāhidī wrote his text to express how the Muslim-Christian debates in the presence of Berke Khan should be conducted. This supports our acceptance that the cause of the anonymous author's writing Risālah is the conversations between Mehmed II (the Conqueror) and Gennadios and the Itikätnâme written in this context. The Risälah has been written expressly to respond to such criticisms. However, it can be said that Mehmed II's discomfort with Gennadius discussion style is a primary effect of those discussions. It can be observed in the fact that the author of the Risālâh includes the issue related to the religious discussion in the presence of the sultan, which Zâhidĩ included in the third chapter, immediately after the introduction of the Risālah. 


\section{Giriş}

Müslüman devletler ister doğuda ister batıda olsun varlık sahasına çıkmalarından itibaren etnik ve dinî bir çoğulculuğu içlerinde barındırmışlardır. Söz konusu devletlerden biri olan Osmanlı da bu çoğulculuğu kendi içinde barındırdığı gibi, vukuu bulan dini tartışmaların doğal bir sonucu onlardan devraldığı İslam dışı dinlere karşı reddiyeler kaleme alma geleneğine yeni metinler ekleyerek onu zenginleştirmiştir.

Ancak bu tür dinî tartışma metinlerine yönelik akademik çalışmalar daha çok İslam'ın Klasik Dönemi olarak adlandırılanla bir dönemle sınırlandırıldığı için, Osmanlı dönemi bu bakımdan genellikle görmezden gelinmiştir. M. Aydın'ın klasik reddiyelerin yanı sıra büyük kısmı Türkçe olan ve on dokuzuncu yüzyılla tarihlenen Hıristiyanlık karşıtı reddiyeleri ele almış olmasından yirmi seneyi aşkın bir süre geçmiş olmasına rağmen ${ }^{1}$, aynı konuyu benzer tarzda geriye doğru, Osmanlı'nın Klasik Dönemi'ni kapsayacak çalışmalar yapılmamıştır. Adang'ın², üçü mühtedi biri Osmanlı âlimi tarafından Arapça kaleme alınmış Yahudi karşıııı dört reddiyenin tahkik, neşr, çeviri ve haklarındaki bir araştırmayı da içeren çalışmaları, klasik dönem Osmanlı reddiyelerine yönelik çalışmaların başlangıcı olmuştur. Aynı metinler hakkında benzer bir çalışma da Aydın ${ }^{3}$ tarafından yapılmıştır. Krstic'in ihtida bağlamında ${ }^{4}$ ve

1 Mehmet Aydın, Müslümanların Hıristiyanlara Karşı Yazdıkları Reddiyeler ve Tartışma Konuları (Ankara: Türkiye Diyanet Vakfi Yayınları, 1998). Bir makale ve yüksek lisans tezi konusu olarak çalışlan İskender b. Ahmed et-Trabzoni ve Risâle fí'r-reddi [ale'l]-milleti'n-Nasrâniyyetibi'lİncîlminkıbeliilmi'l-kelâmadlı eseri de keza on dokuzuncu yüzyıla aittir. Muhammet Tarakçı, “İskender b. Ahmed et-Trabzoni’nin Hıristiyanlığa Reddiyesi”, Türkiye'de Dinler Tarihi (Dünü, Bugünü ve Geleceği), 04-06 (Aralık 2009, 2010), 305-318; Ensar Gülmez, İskender Trabzonî'nin Hirıstiyanlık Eleştirisi: Kelam İlminde Reddiye Geleneği), İstanbul: Ravza Yayınları, 2018).

2 Camilla Adang-SabinaSchmidtke, Contacts and ControversiesbetweenMuslims, Jews and Christians in the Ottoman Empire and Pre-modern Iran (Wurzburg: Orient-Institute, 2016); Adang-Schmidtke, Muslim Perceptions and Receptions of the Bible (Atlanta: Lockwood Press, 2019), 327-411; bu konuyla alakalı yapılmış olan diğer çalı̧̧malar için bk. Fuat Aydın, "İslam Reddiye Geleneği ve Taşköprizâde Ahmed B. Mustafa'nın (968/1561) Risâle Fî̀'r-Redd Ale'lYehûd Adlı Risâlesi Üzerine Bir Araştırma”, darülfünun ilahiyat, 31 (2020): 299-353.

3 Fuat Aydın, Osmanlı Dönemi Yahudilik Eleștirileri (Ankara: Eskiyeni Yayınları, 2020).

4 Biri Yahudi diğerleri Hıristiyan olan dört mühtedi hakkında bk. Tijana Krstic, Osmanlı İhtida Anlatılarl, 15-17. Yüzyll (İstanbul: Kitap Yayınevi, 2015), 152-178. Krstic'in de incelediği Tercüman Murad b. Abdullah'la ilgili yapılmış bir Yüksek Lisans tezi için bk. İsmail Emre Pamuk, "Bir 16. Yüzyıl Okuryazarının Zihin Dünyası: Tercüman Murad ve Tesviyetü’t-Teveccüh ile'l-Hak Adlı Eseri” (Yüksek Lisans Tezi, İstanbul Üniversitesi, 2021). 
Thomas'ın $C M R$ 'nin ${ }^{5}$ bir parçası olarak ele aldıkları, Osmanlı döneminde yazılmış Hıristiyanlık karşıtı reddiye metinlerinden ulaşılabilenler, yazarı, yazıldığı tarih, içeriği ve Hıristiyan-Müslüman ilişkileri bağlamındaki önemine dair başlıklar altında incelenmiştir. $C M R^{\prime}$ nin $^{6}$ ilgili ciltlerinin yayımlanmasından önce olanlar hariç, bu metinler yayına hazırlanmadığ 1 gibi, haklarında müstakil herhangi bir çalışma da yapılmamıştır

Elinizdeki makalenin amac1, on beşinci yüzyılın ortasıyla tarihlenen bir Hıristiyanlık karşıtı reddiye kalksın metninin yazıldığı bağlam, yazılma gerekçesi, içeriği, kaynakları vb.yi ele almaya ve daha önce bu metin hakkında verilen bilgilerdeki bir takım yanlışları düzeltmeye çalışmaktır.

\section{Risâle'nin ismi}

Makalenin konusunu teşkil eden Risâle ${ }^{7}$, 1454/55 tarihinde kaleme alınmış Hıristiyanlık karşı1ı daha doğrusu Hıristiyan iddialarını eleştirerek İslam'ı savunmayı hedefleyen bir reddiye-dir. Bu reddiyenin varlığına dair modern dönemdeki ilk kayıt Steinschneider ${ }^{8}$ ve Fritsch' in ${ }^{9}$ çalışmalarında yer alır. Bunlar içinde ikincisi, nüsha tanıtımının yanı sıra muhtevaya yönelik nispeten ayrıntılı bir bilgiyi de içerir.

5 Bu, David Thomas editörlüğünde yayına hazırlanan A History of Christian-Muslim Relationship adlı serinin kısaltmasıdır. Bundan sonra söz konusu esere, bu kısaltmayla atıfta bulunulacaktır. Bu seride tanıtımı yapılan Osmanlı dönemi Hıristiyanlık eleştirilerine dair bk. Betül Avcı, “Atinalı Mühtedi Mehmed”. Christian-Muslim Relations A Bibliographical Histor (1500-1900), ed. David Thomas, erişim: http://dx.doi.org/10.1163/2451-9537_cmrii_COM_27234.; "Atinalu Kapucî[nin] Habîbullâh'ın Evsâfin Tevrît'te ve İncîl ve Zebûr'da Görüb Îmâna Geldüğidir". CMR, erişim: http://dx.doi.org/10.1163/2451-9537_cmrii_COM_27235; "Derviş Mehmed". CMR. erişim: http://dx.doi.org/10.1163/2451-9537_cmrii_COM_27226; "Papasnâme". CMR. erişim: http://dx.doi.org/10.1163/2451-9537_cmrii_COM_27227.

6 Klasik Osmanlı dönemi Hıristiyan reddiyelerinden Derviş Ali en-Nakşibendî ve en-Na tü'nnebi fi'l-İncîl'i hakkındaki çalışmalar için bk. Cevahir, Hülya. "Derviş Ali En-Nakşibendi ve Na'tü'n-Nebifi'l-İncil İsimli Eserinin Tahkik ve Tercümesi”' (Yüksek Lisans Tezi, Sakarya Üniversitesi, 2008); Monika Hasenmüller, "Die Beschreibung Muḥammads im Evangelium. Einemuslimische Polemik gegendie Christenaus dem osmanischen Reich", Adang-Schmidtke, "Contacts and Controversies", 83-196. Krstic'in ve Avc1'nın haklarında bilgi verdikleri, Kapıc1 Mehmed hakkında ayrıntılı bir araştırma, metinin Latinizesi ve Türkçesi için bk. İrfan İnceFuat Aydın, "Bir 17. Yüzyıl İhtida Anlatısı: Bir Atinalı Mühtedî, Bir Osmanlı Kadısı", Sahn-ı Semân'dan Dârülfünûn'a Osmanlı'da İlim ve Fikir Dünyası Âlimler, Müesseseler ve Fikrî Eserler XVII. Yüzyll, 2017 (İstanbul: Zeytinburnu Belediyesi, 2017), 507-581.

7 Her ne kadar Fransız Milli Kütüphanesi'nde er-Redd ale'n-nasârâ olarak kaydedilmiş olsa da -birazdan ele alınacă̆ üzere- metnin içinde ve üzerinde yazarı tarafından ona verilmiş herhangi bir isim olmadığından, bundan sonra metne yalnızca Risâle olarak gönderme yapılacaktır.

8 M. Steinscheneider, Polemische und apologetische Literatur in arabischer Sprachezwischen Muslimen, Christenund Juden (Leipzig: yy, 1877), 42-43.

9 E. Fritsch, Islam und Christentum im Mittelalter (Breslau: Müller und Sefert, 1930), 36-38. 
Yakın zamanlardaki bir çalışma da Thomas'ın editörlüğünde üretilen CMR içinde ise, yazar, içerik, Müslüman-Hıristiyan ilişkilerindeki önemine dair bir bölüm, Risâle' nin muhtevası ve niteliğiyle ilgili kısa bir tanıtım yazısına yer verilmiştir ${ }^{10}$.

Risâle'yi ilk zikreden Steinschneider onun için Hücecü'l-milleti'l-Hanifiyye ve cevâbu külli suâl ismini verir ${ }^{11}$. Fritsch, metnin ismi olarak yalnızca Risâle 'yi, ${ }^{12}$ Thomas ise Steinschenider'inkini zikreder ${ }^{13}$. Kitabın bize kadar gelen iki yazma nüshasının bulunduğu iki kütüphaneden Fransız Milli Kütüphanesi metnin ismini (1463) Red ale'n-nasârâ, ikincisi olan Leiden Kütüphanesi (2086) ise risâle ismi olarak “Apology of Islam Against the Christianity/Hıristiyanlığı Karşı İslam'ın Savunusu"nu zikreder. Steinschneider ve onu takiben Thomas'ın isim olarak zikrettikleri, metinde "Onun mübarek ismiyle bir risale yazmayı ve orada Hanîf dininin delillerini ve gizli ve açık olarak varit olan her türlü sorunun cevabını zikretmeyi istedim" ${ }^{14}$ şeklinde yer alan ifadeden çıkartılmıştır. Bu ifade Risâle'nin -daha sonra üzerinde daha ayrıntılı olarak duracağımız- yegâne kaynağı olan ve yazarı tarafindan er-Risâletü'n-Nâsıriyye ${ }^{15}$ olarak kaydedilen metinde de aynı şekilde geçer ${ }^{16}$. Bu da onun Risâle için düşünülen bir isimden daha ziyade metnin içeriğini anlatmaya yönelik bir ifade olduğunu gösterir.

Dolayısıyla da Risâle'nin kendisinde yazarı tarafından verilmiş ne içinde ne de sonradan kitabın kapak sayfasına eklenmiş herhangi bir isim mevcuttur.

\section{Risâle'nin Yazarı}

İslam telif geleneğinde yazar (istisnalar olsa da genel itibariyle) besmele, hamdele ve salveleden sonra و و بعد ifadesinin arkasından adını zikrederek metnin sebeb-i telifini dile getirir. Bazen yazar ismi metnin hatime kısmında yazarın kendisi ya da istinsah yapan tarafından bir kez daha tekrarlanır. Bazen de metnin kapak sayfasında bir başkası tarafından kaydedilir.

10 David Thomas, "Hujjaj al-milla l-Hanafìye ve cewabkull sual", CMR, 5:419-420.

11 Steinscheneider, Polemische und apologetische Literatur, 42.

12 Fritsche, IslamundChristentum im Mittelalter, 36.

13 Thomas, "Hujjaj al-milla l-Hanafìye ve cewabkull sual", CMR, 5: 419.

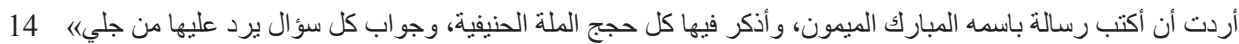
(أو مكنون,

Fransa 3b-4a; Leiden 2b-3a.

15 Zâhidî, er-Risâletü'n-Nâsıriyye, thk. Muhammed el-Misrî (Kuvyet: Menşûrâtu Merkezi'lMahtûtât ve'türâs ve'l-vesâik, 1993/1414), 75.

16 ez-Zâhidî, er-Risâletü'n-Nâsıriyye, 27. 
Bu Risâle'nin ne besmele, hamdele ve salvele sonrasında ne hatime ne de kapak sayfasında yazar ismine dair herhangi bir ifade yer alır.

Yazar, besmele, hamdele ve salveleden sonra, “Allah'ın yüce rahmetine muhtaç bu zayıf ve hakir kul der ki" ${ }^{17}$ diyerek ismini zikretmez. Risâle herhangi bir klasik bibliyografi kitabında yer almadığından, onlardan hareketle de zikredilmeyen yazar ve kitap ismine ulaşma imkânı da yoktur.

Ancak yine de metin içinde yazarın kim olduğunu tespitte işimize yarayacak ipuçlarını bulmak mümkündür. Bunlardan birincisi, Fatih Sultan Muhammed'in adının; ikincisi kitabın yazıldığı tarihi verirken, nübüvvet asrından 859 sene geçtiğinin ifade edilmesi ${ }^{18}$ ve Risâle'nin bir yerinde söz konusu ettiği konuların kelama dair el-Mücteba ya da el-Müctebâfi 'l-kelâm adındaki eserinde ele alındığının zikredilmesidir. İlk iki bilgi elimizdeki iki nüshada da yer aldığından yazarın, Fatih'in döneminde ve en azından 859/1454/5'te hayatta olduğunu kesin olarak söyleyebiliriz.

Yukarıdaki bilgiler Risâle'nin yazarının yaşadığı dönemi kesin olarak bilmemizi sağlasa da kim olduğu hakkında bir şey söylemez. Ancak eğer el-Mücteba'nın yazarını belirleyebilirsek, yazarın kim olduğu ortaya çıkmış olur.

Hem Yazmalar Genel Müdürlüğü hem de İsam Türkiye Kütüphaneleri Kataloğu tarandığında el-Mücteba isminin geçtiği çok sayıda metnin olduğu görülmektedir. Ancak el-Müctebâ adıyla başlayan yalnızca iki kitap vardır. Bunlardan birincisi Zâhidî’nin el-Müctebâ şerhü muhtasari'l-Kudûrî adlı fikıh; diğeri de Nesâî'nin Sünen adıyla meşhur hadis kitabıdır. Kâtib Çelebî'nin Keşfu'z-zunûn'unda mezkûr Kudûrî ve Sünen şerhlerine ${ }^{19}$ ilave olarak İbnü'l-Cevzî’nin el-Müctebâ fî envâ 'in mine'l-ulûm ${ }^{20}$ ve Zâhidî'nin el-Mücteb f' 'i'l-Usûl ${ }^{21}$ adlı kitabını zikreder. Dolayısıyla da Risâle'de zikredilen el-Mücteba fi'l-kelâm ya da kelama dair el-Müctebâ isminde müstakil herhangi bir kitap yoktur. Ancak az önce Kâtip Çelebî’nin zikrettiği üzere el-Müctebâ fi'l-Usûl adında Zâhidî'nin bir kitabı vardır²2. Konumuzu teşkil eden Risâle'yle olan ilişkisine yukarıda atıfta bulunduğumuz Risâletü'n-Nâsıriyye'nin yazarı da el-Mücteba adlı kitabında ilgili konuları ele aldığından söz eder. Bu da

فيقول العبد الضعيف الحقير المحتاج إلى رحمة الله العلي الكبير اما بعد 17 Fransa 2b.

18 Leiden $47 \mathrm{a}$.

19 Bk. el-Müctebâ, 807, 808, 1264, 1276 vs.

20 Bk. 1264.

21 Bk. 1269.

22 Ayrıca bk.http://ktp.isam.org.tr/?url=makaleilh/findrecords.php;http://www.yazmalar.gov.tr// basit-arama?q=el-Mücteba . Erişim tarihi, 21.09.2021 
Zâhidî'nin el-Müctebâ adıyla kastettiği kitabın onun el-Müctebâ fi'l-Usûl adlı eseri olduğu anlamına gelir. Risâle'mizin yazarı Risâlütü'n-Nasıriyye'yi ufak tefek değişiklikler dışında aynen istinsah ettiğinden Zahidî'nin kendi kitabının adını zikrettiği yeri de kopyalamış, ancak kitabın fıkıh usulü mü yoksa kelam hakkında mı olduğu şeklindeki karmaşaya son vermek için de kitaptan sonra “fi'l-kelâm" ifadesini eklemiştir. Bununla da el-Müctebâ fi 'l-Usûl' 'n müstakil bir kitap ismi olduğunu değil de yukarıda alternatif bir okuma olarak zikrettiğimiz gibi el-Mücteba olarak da bilinenin el-Müctebâ fi'l-Usûl'un genel olarak kabul edildiği üzere kelâma dair bir eser olduğunu göstermek istemiştir ${ }^{23}$.

Müellifimizin "fi'l-kelâm" ilavesi bize onun kimliği hakkında ilave bir bilgi sağlamasa da medresede okuduğu kitaplar arasında yer alan Kudûrînnin meşhur bir şerhini ${ }^{24}$ kaleme alan kitabın yazarını çok iyi tanıdı̆̆ı; yani iyi bir Hanefi mezhebi literatür bilgisine sahip olduğunu gösterir. Ancak bu kadar dakik bilgiye sahip olan birinin, aşağıda ifade edildiği üzere, metninde hem -eğer müstensihten kaynaklanmamışsa- gramer hatalarının hem de birtakım tutarsızlıkların bulunmasına nasıl izin verdiği ise, izaha muhtaç bir durumdur.

Şimdiye kadar söylediklerimizi özetleyecek olursak, yazarın kimliği hakkında, Risâle'sini 845/1454/5'te yazdı̆̆ın1; Risâle'de yer verdiği dönemin hakanın huzurundaki dini tartışmanın nasıl olması gerektiğine dair ifadelerden FatihGennadius tartışmasına tanıklık edecek kadar Fatih'e yakın, Gennadius'un yazdığı İtikatnâme'ye vakıf olup Risâle' yi yazmak zorunda kalan biri olduğunu söyleyebiliriz.

\section{Risâle'nin Nüshaları}

Risâle'nin günümüze ulaşan iki nüshasına sahibiz. Bunlardan birincisi II. Mehmed'e ithaf edilmiş ve muhtemelen daha eski tarihli olan nüsha, Fransız Milli Kütüphanesinde 1463 numarayla ve Traite anonyme de polemique contreles chretiens [Radd 'alâl -nasara] adıyla kayıtlıdır. Metin, 2-63 varakları arasında yer alır. Her sayfa, sülüsle yazılmış yedi satırdan oluşmaktadır. Metnin kenarlarında tashihler ve modern dönemdeki bir okuyucusu tarafından kenarlara eklenmiş (muhtemelen Almanca, dolayısıyla da ondan modern dönemde söz eden Steinschneider ya da Fritsche'e ait olan) notlar bulunmaktadır. Metin, mikrofilimden pdf formatına aktarılmıştır. Bölüm başlıkları ve başka bazı yerler kırmızı mürekkeple yazılmış olduğu anlaşılmaktadır. es-Sultân Muhammed ismi hem punto hem de renk olarak

23 Şükrü Özen, “Zâhidî”, TDV İslam Ansiklopedisi (Ankara: TDV Yayınları, 2013), 44/83-85.

24 Zâhidî'nin el-Müctebâ şerhu mutasari'l-Kudurî’nin el yazması nüshaları için bk. http://ktp. isam.org.tr/?url=makaleilh/findrecords.php erişim tarihi 29.09.2021 
ilk bakışta göze çarpacak kadar büyük yazılmış olup, öncesine ve sonrasına üç nokta konulmuştur ${ }^{25}$. Metnin tamamı harekelenmiştir.

İkinci nüsha Leiden Üniversitesi kütüphanesinde 976 numarayla ve Apology of Islam Against the Christianity (Hıristiyanlığa Karşı İslam'ın Savunusu) adıyla kayıtlıdır. Jenerik sayfasında "sahibu ve maliku Ahmed b. Mustafa, sene 1043 Şaban/1634”26 kaydı yer almaktadır. Bu nüsha da Fransız Milli Kütüphanesi’ndeki gibi 63 varak halinde olup; aynı şekilde her sayfada yedi satır yer alır. Diğerinden farklı olarak 63b'de ise yalnızca dua cümlesi bulunur. Fransa nüshasında yer alan 2b-3a kısmı, bu nüshada atlanmıştır. Çok sayıda küçük tashihler, az sayıda kelime açıklamaları vardır. Bölüm başlıkları, nispeten daha büyük siyah ve cümle başları kırmızı mürekkeple; bütün olarak ise metin sanatsal değeri olan sülüs bir yazıyla kaleme alınmış ve baştan sonra harekelenmiştir.

Birinci nüshada tashih olarak girilen metinler, ikincisinde metnin içinde bulunmaktadır (Fransa 30a-Leiden 29a vs.). Birincideki çok az tashihin, ikincisinde de tashih olarak hamişte yer alması (Fransa 15a-Leiden 14b; Fransa 17a-Leiden16a), kesin karar vermeyi zorlaştırsa da; ilkindeki tashihlerin büyük kısmının Leiden

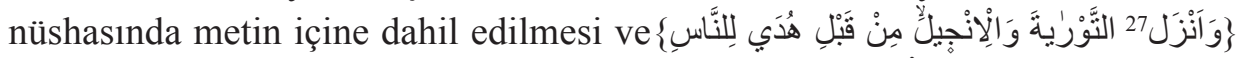

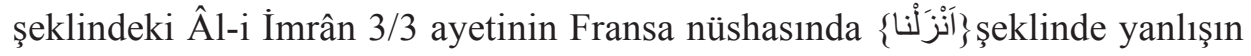
Leiden nüshasında da tekrarlanmış olması sebebiyle, ikincinin birinciden istinsah edilmiş olduğunu söyleyebiliriz. Ancak bu, her ikisinin de istinsah edilmiş nüshalar olduğunu göz önünde bulundurduğumuzda, bir başka nüshadan istinsah edilmiş olmaları ihtimalini de ortadan kaldırmamaktadır.

Leiden nüshasında zaman zaman kelime açılamalarına ve Fransa nüshasında bulunmayan salat ü selamlara yer verilmesi de, söz konusu ilavelerin okuyucusu tarafından eklendiğini akla getirmektedir.

\section{Risâle'nin Yazıldığı Ortam ve Yazılma Sebebi}

Risâle'nin yazılma tarihi, yazarın zikrettiği tarihten de anlaşılacağı gibi, İstanbul'un fethinden altı ay ya da bir buçuk sene sonrasıdır. Fatih bir yandan, savaş öncesi ve sonrasında önemli sayıda kişinin İstanbul'dan ayrılmalarıyla azalan şehrin nüfusunu, hem gidenleri geri getirme hem de yeni yerleşimciler getirerek nüfusu arttırmaya ve şehri imar etmeye çalışmıştır. Öte yandan hem şehirdeki ana

25 Fransa 3a.

صاحب و مالك الحقير Leiden jenerik sayfası b. Bir üstte "صاحب و مالك احمد ابن مصطفي سنة זء ـ اشعبان، 26 yer alan ve Mustafa kısmının okunmadığı yazının altına birincisi yazılmış.

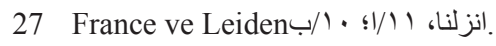


nüfusu oluşturan Rumlar, Ermeniler ile Yahudilerin hem de daha çok Galata'da meskûn ticari kolonilere sahip olan Venedik ve Cenevizlilerin fetih sonrası yaşam tarzlarını, garanti altına alan düzenlemeler yapmıştır. Fetih öncesinden, Gregory Mammas'ın Roma'ya gitmesinden $(1451)^{28}$ beri boş olan patriklik makamına, Roma ile birleşme düşüncesine karşı olan, Osmanlılar tarafından önce esir alınıp Edirne'ye götürülen, sonra serbest bırakılan keşiş, filozof ve halk tarafından sevilen George Scholaris' 'i II. Gennadius adıyla Haziran 1454'de patrik olarak atamış, resmi tören ise 6 Ocak 1455 'te yapılmıştır. ${ }^{29}$. Onu, cemaatin hem dinî hem de dünyevi işlerinin başı ve devletle cemaat arasındaki aracı kılarak patriklik makamının yetki alanını Bizans dönemine nazaran genişletmiştir. Benzer şekilde Bursa'da bölge metropoliti olan Ermeni piskopos Hovakim/Hovagim'i İstanbul'a çağırmış, İstanbul Ermeni Patrikliğini kurmuş, onu da patrik olarak atamıştır. Ermenilerin yanı sıra, diğer Ortodoks cemaatleri (Süryaniler, Kıptiler, Gürcüler, Keldaniler, Habeşlileri) de onun idaresi altına vererek sorumluluğunu arttırdığı gibi konumunu da güçlendirmiştir ${ }^{30}$. Yayımlanan bir fermanla, Yahudilere de daha önce olduğu şekilde yaşamlarına devam edebilecekleri söylenmiş ve Bizans Yahudilerinin son hahambaşısı olan Rav Moşe Kapsali de Fatih tarafından Osmanlıların ilk hahambaşısı olarak atanmıştır ${ }^{31}$.

Her ne kadar yazar sebeb-i telif olarak bir şey zikretmese de "zamanımız hakanının huzurunda" yapılan Hıristiyan-Müslüman tartışmasından ve usulünden bahsetmesinden, söz konusu sebebin, müellifin yaşadığı zamandaki hakanın huzurunda icra edilen böyle bir tartışma olduğu anlaşılmaktadır.

Osmanlı döneminde Fatih öncesinde sultanın huzurunda Hıristiyan-Müslüman dini

28 Gregory Mammas için bk. https://en.wikipedia.org/wiki/Gregory_III_of_Constantinople. Erişim tarihi 22.09.2021.

29 Aristeides Papadakis, "Gennadius II and Mehmed II the Conqueror", Byzantion, 42 no. 1 (1972): 91, 94. Gennadius'un patrik seçilmesi, atanması, yapılan tören ve verilen beratla ilgili olarak bk. Steven Runciman, Konstantiniyye Düştü, çev. Derin Türkömer, (İstanbul: Milliyet Yayınları, 1972), 239/42. Ayrıca Gennadius ve Fatih dönemi sonrası Patrik seçimleriyle ilgili olarak bk. Salih İnci, “Osmanlı Dönemi Fener Rum Patriklerinin Seçimi”, İstanbul Üniversitesi İlahiyat Fakültesi Dergisi 53 (2015), 9-58.

30 Abdurrahman Küçük, Ermeni Kilisesi ve Türkler (Ankara: Berikan Yayınevi, 2005), 84, 184. Ayrıca bk. Canan Seyfeli, "İstanbul Ermeni Patrikhanesi”, TDV İslam Ansiklopedisi (Ankara: Türkiye Diyanet Vakfı Yayınları, 2016), 16/668-671; Canan Seyfeli, İstanbul Ermeni Patrikliği (İstanbul: Çizgi Kitapevi Yayınları, 2019).

31 Hahambaşllık ve tarihi için bk. Hatice Doğan, Osmanlı Devleti'nde Hahambaşılık Müessesesi (İstanbul: Gözlem Gazetecilik Basın Yayın A.Ş., 2003). 
tartışmaları az da olsa vukuu bulduğu gibi ${ }^{32}$ Fatih döneminde de böyle tartışmaların yaşandığını biliyoruz. Birincisi Patrik Gennadius'la ikincisi ise Amiroutzes'le yapılandır. Amiroutzes'le yapılan tartışma, risalenin kesin olan yazılış tarihinden çok sonra 1471'de gerçekleşmiştiri3 ${ }^{33}$. Dolayısıyla Risâle'nin yazılma sebebi, yazılma tarihinden öncekiler ve sonrakiler olamayacağına göre en muhtemel neden, Patrik Gennadius'la yapılan dini müzakere gibi görünmektedir.

Patrik Gennadius'a atfedilen İtikadnâme hakkında yazanların hepsi, onun Fatih'le aralarında gerçekleşen bir görüşmenin sonucunda ortaya çıktı̆̆ hususunda hemfikirdirler.

32 Bunlardan iki tanesi çok iyi bilinmektedir. Birincisi Orhan Gazi zamanında Gelibolu'da esir olarak Türklerin eline düşen Bizanslı teolog ve fillozof Gregory Palamas'ın Bursa'da Orhan Gazi’nin huzurunda ve Bursa'dan İznik'e giderken yolda ve İznik’te yaptığı tartışmalar (135455); ikincisi ise, Yıldırım Bayezid'ın Kadı Burhaneddin'e yönelik seferine katılmasını istediği vasalı olan İmparator II. Manual Paleilogos'un; kış mevsiminden dolayı, konaklanan Ankara'da Hacı Bayram Veliyle (Aralık, 1391) yaptığı tartışmadır. Gregory Palamas'ın hayatı, eserleri ve Müslümanlarla olan dinî tartışmaları için bk. Hüsnü Demircan, Orhan Gazi ve Gregory Palamas (Yüksek lisans tezi, Ankara Üniversitesi, 1993); Halil İnalcık, “Orhan (ö. 763/1362)”, TDV Íslam Ansiklopedisi (Ankara: TDV Yayınları, 2007), 33/383; ayrıca eserleri ve Osmanlı ulemasıyla yaptığı tartışmanın içeriğine dair bk. Johannes Pahlitzch, "Gregory Palamas”, Christian-Muslim Relationship (1350-1500), ed. David Thomas and Alex Mallet, (Leiden-Boston: Brill, 2013), 5/101-108. II. Manuel Palailogos ve Hacı Bayramla olan tartışması için bk. Mustafa Daş, "XIV. Asırda Dinler Arası İletişim: Bizans İmparatoru II. Manuel Palaiologos ve Hacı Bayram Veli'nin Ankara'da Yaptıkları Tartışma”, XI. ve XVIII. Yüzyıllar Íslâm-Türk Medeniyeti ve Avrupa Uluslararast Sempozyum $=X I$. to XVIII. Centuries Islamic-Turkish Civilization and Europe International Symposium, 24-26 Kasım, 2006 (İstanbul: 2006), 85-92; Tomoo Uegaki, Byzantine Religious Dialogues with Muslims in the Fourteenth and Fifteenth Centuries, (MR, University of Birmingham, 2015), 12-47. Michel Balivet, "1391'de Ankara'da İlahiyat Konulu Bir Münazara: Hacı Bayram Veli ve II. Manaul Paleilogos”, Annie Pralongo (edt.), Bizans, Yapılar, Meydanlar, Yaşamlar, çev. Buket Kitapçı-Bayrı (İstanbul: Kitapyayınevi, 2011), 239248. Ayrıca bk. Papa XVI. Benedikt'in 12 Eylül 2006'da daha önce hocalık yaptığı Regensburg Üniversitesi'ne “İman-Akıl-Üniversite” başlığı altında yaptığı konuşmada, II. Manuel'in Hac1 Bayramla yapmış olduğu bu tartışmayı kayda geçirdiği metinlerden naklen, Hz. Peygamber'in kan ve göz yaşından başka ne getirdiğine dair ifadeleri üzerin yazılan şu yazı, Mehmet Görmez, "Hacı Bayram Veli, II. Manuel Palailogos ve Papa XVI: Benedikt, Papa Benedikt'in Konuşmasının Tarihi ve İlmi Değeri Üzerine”, Diyanet Aylık İlmi Dergi, 190, (Ekim 2006): 1/6.

33 George Amiroutzes'in Fatih'le olan dini diyaloğu ve bunun metne aktarılmış şekli, Yunanca olmasa da bugün bilinmektedir. Ancak bu konuşma, 1471'de gerçekleştiği ve bizim Risâle'miz $1454 / 5$ 'te yazılmış olduğu için onu burada konu edinmeye gerek yoktur. Amiroutzes ve Fatih'le olan dini diyaloğu için bk. Uegaki, Byzantine Religious Dialogues, 48-63; Angeliki Ziaka, "Rearticulating a Christian-Muslim Understanding: Gennadios Scholarios and George Amiroutzes on Islam”, Studies in Church History, 51 (2015), 154-55, 161-3. 
Fatih-patrik buluşmasının ise, bir kaynağa göre tesadüfle ${ }^{34}$; ancak genel olarak bilinçli bir şekilde Fatih'in Gennadius'u ziyaret etmek istemesiyle başladığı kabul edilir $^{35}$. Fatih, maiyetiyle Pammakaristos Manastırı'na (bugünkü Fethiye Camii) gitmiş odasından inen patrik onu karşılamış ve görüşmüşlerdir. Sorulan sorulara verilen cevaplar karşısında bir şey yapılmayacağına dair Fatih tarafından güvence verilmesi üzerine, Gennadius Fatih'in Hıristiyanlıkla ilgili sorularını cevaplamışıtır. Patriğin tavrı ve bilgisi Fatih'in onu sevmesi ve kendisine karşı saygı duymasıyla sonuçlanmıştır ${ }^{36}$. Fatih'in daha sonra yine Pammakaristos manastırında patrikle iki kez daha buluştuğu ve dini konuları konuştuğu nakledilir. Bu konuşmalar sonrasında Fatih, patrikten Hıristiyanlık hakkında kendisine anlattığ 1 şeylerin özünü yazılı biçimde vermesini istemiş, o da "İnsanlığın Kurtuluşu İçin Yegâna Yola Dair” adlı metnini hazırlamıştır. Ancak Fatih Türkçeye çevrilen ve kendisine teslim edilen bu metnin hem uzun hem de anlaşılmasının zor olduğunu söyleyerek onu kısaltmasını istemiştir. Bunun üzerine patrik, öncekiyle aynı adı taşıyan ancak bugün Gennadius'un İtikadnamesi, bazen de yalnızca İtikadnâme adıyla meşhur olan metni hazırlamıştır. Hazırlanan bu yeni metin, Mahmut Çelebi’nin babası Karaferyalı Kadı Ahmed tarafından Grek harfleriyle (Karamanlıca) Türkçeye çevrilmiştir ${ }^{37}$.

34 Aristeides Papadakis, “Gennadius II and Mehmet The Conqueror”, Byzantion 42 no. 1 (1972), 95.

35 T. Halas1-Kun, “Gennadius' Confession of Faith”, Archivum Ottomanicum, 12 (1987-1992), 5-6.

36 Papadakis, "Gennadius II and Mehmet The Conqueror", 95. Bu ve sonraki ziyaret ve müzakerenin asıl sebebinin ne olduğu kesin olmamakla birlikte, Fatih'in tebaasının önemli bir kısmını oluşturan Hıristiyanları daha iyi tanımak, bunu da önemli gördüğü bir Hıristiyan alimle yapmak istemiş olması en makul açıklama gibi görünmektedir. Ancak daha kurgusal gerekçeler de ileri sürülmüştür. Mesela bu görüşmeye ve Gennadius'un Fatih için Hıristiyan inanç esaslarına dair bir risale yazdığına dair haberler batıda yayıldığında, Fatih'in Hıristiyan olduğu, bütün ülkesini Hıristiyanlaştırmak istediği şayiası yayılmıştır. Bunları ve onun annesinin bir Hıristiyan olup onu Hıristiyan olarak yetiştirdiği iddiaları üzerine Papa II. Pius Fatih'e bir mektup yazarak, Hıristiyanlığın İslam' dan üstün olduğu hususunda onu ikna etmek ve Hıristiyan olduğu takdirde kendisini doğunun ve Bizans'ın imparatoru olarak isimlendireceklerini söyleyen bir mektup kaleme almıştı. Bu mektup için bk. Yusuf Yıldız, Papa Pius II'un Fatih Sultan Mehmet'e Mektubu, (Ankara: Akçağ Yayınları, 2018). Fatih'in Gennadius'la görüşme sebeplerine dair bk. D. Sakel, "Three Talesfor Sultan? Three Tales on Mehmed the Conqueror and Patriarch Gennadius", British Jounal of Middle Eastern Studies, 35/2 (Aug. 2008), 228; Gennadius'un Fatihle ilişkisi (ayrıca Gennadius"un bilgeliğini ortaya koyan 16. yüzyıl efsanevi anlatıları için bk. Sakel, "Three Tales for Sultan?, 233-38); Halas1-Kun, "Gennadius' Confession of Faith", 6; Papadakis, "Gennadius II and Mehmet The Conqueror", 99-100. Papa Pius II'nin mektubu hakkında bir değerlendirme için bk. Ozden Mercan, Constructing A Self-Image in the Image of Other: Poltical and Religious Interpretations of Pope Pius II'Letter to Mehmed II (1461) (MA Thesis, Central European University, 2008).

37 Metnin latinizesini Aurel Decei, "Yenadiyus İtikatnâmesinin Metni”, Fetih ve İstanbul, 2/7-12 (1954):203-210. Karamanlıca, Latinizesi ve günümüz Türkçesiyle ise, Fehmi Dinçer neşretmiştir. Künyesi için bk. aşağıdaki dipnot. 
Gennadius'un metni, farklı yayımlarda farklı biçimlerde paragraflara ayrılmış olsa da genel olarak yirmi paragraftan oluşmaktadır. ${ }^{38}$. Paragraflar bazen "İtikadımız şunun üzerinedir, inancımız şundan oluşur, şuna inanırız/inanılır ki" ya da "İnancımız şudur" şeklinde çevrilebilen ifadelerle başlamakta, bazen de metin içinde aynı ifadeler tekrarlanmaktadir ${ }^{39}$.

Kabaca üç bölüme ayrılabilecek olan İtikadnâme'de Gennadius birinci kısımda, Tanrı'dan ve niteliklerinden sonra Hıristiyanlıktaki üç tanrı anlayışından söz eder. İkinci kısımda teslis anlayışının ikinci unsurunu oluşturan İsa Mesih hakkında ayrıntılı bilgi verir. İnsanların ölümden sonraki durumlarına dair kısa bir paragraftan sonra, dördüncü kısımda, Hıristiyanlığın hak din oluşunu yedi delil bağlamında göstermeye çalışır.

"Tanrı vardır, bütün varlığı yoktan yaratmıştır; cisim değildir, her yerdedir, bir mekânı yoktur; âkıl ve akıldır, diridir”. Bu sıfatlar mahlûkâtında da vardır; ancak bunlar Tanrı'da zâtidir, diğerlerindeki sıfatlar da O'ndan kaynaklanır. Üç sıfatı vardır ve diğer bütün sıfatların kaynağı bunlardır. Tanrı bu üç sıfatıyla dünyanın yaratılışından önce de vardır. Dünyayı bu sıfatlarla yarattığı gibi, dünyadaki her şeyi de bunlarla devam ettirir. Biz bu üç sıfatı, üç öz, üç biçim olarak adlandırırız. Tanrının tekliği parçalanmadığından bu üç sıfata sahip yalnızca bir Tanrı vardır. Bunlar, söz, akıl ve iradedir. Bu üçe, tanrı deriz. Akıl ve irade duygusu bir kimsenin ruhunda olduğu gibi bunlar da tek bir ruhtur. İnsandan doğan kişiyi, İnsan oğlu dediğimiz gibi Yaratıcının Kelimesine de Tanrının Hikmeti, Tanrının Gücü, Tanrının Oğlu; Tanrısal İradeye, Kutsal Ruh, Tanrısal Sevgi; Aklı da Baba diye isimlendiririz. Bunun sebebi ise, onun hiç kimseden doğmaması, ancak Kelime'nin ve İrade'nin ondan doğmuş olmasıdır. Kelime ve Kutsal Ruh, ebedi olarak ondan gelir ve ebedi olarak da onunla birliktedir, bundan dolayı da biz, yaratıcıyı tek Tanrı olarak isimlendiririz. Tanrı, bu dünyayı Kelimesiyle, Hikmetiyle, gücüyle ve Kutsal Ruh'la yaratmıştır.

38 Burada esas olarak Fehmi Dinçer’in , "1584 Yılında Karamanlıca Alfabe İle Yazılmış Bir İtikatname”, https://www.academia.edu/9548404/Fehmi_Dinçer_1584_yılında_yazılmış_ Gennadius_Scholarius_İtikatnamesi, adlı makalesindeki Latinize metni kullanılmış; ancak Hem Halasi-Kun'un hem de Papadakis'in İngilizce tercümeleri karşılıklı olarak okunmuştur. Gennadius'un metni ilk olarak Martinis Crusius, Turco graciae libriocto, (Basileae: 1584), 11-119'da Yunancas1, Yunan Harfleriyle Türkçe çevirisi ve Latincesi birlikte yayımlanmış olup, hakkında en çok çalışma yapılan eseridir. Eserin modern dönemde ortaya çıkışı, modern dönemde ne zaman gündeme girdiği, bize kadar gelen el yazması nüshaları ve bunların şimdiye kadar yapılmış olan yayımları hakkında Halasi-Kun ve Uegaki'nin metinlerine bakılabilir.

39 Bunlar için bk. Dinçer, "1584 Yılında Karamanlıca Alfabe ile Yazılmış Bir İtikatname”. 
Tanrı, Musa'nın kitabına inanan İsraillilerin dışındaki putperestleri kurtarmak için Kelimesi ve Kutsal Ruh'la onları insan biçiminde doğru yola iletti. Kelimesi, insanlarla konuşmak için insan biçimini aldı. Tanrı, hakikati Kudüs'e vahiy eyledi. Kutsal Ruh'la havarilerini aydınlattı ve güçlendirdi. Bunu da onların hakikat aşkıyla, hakikati dünyaya anlatmaları, dünyayı günahtan kurtarmak ve mahlûkatını Yaratıcı Rabbe getirebilmek için ölen İsa gibi olmaları için böyle yaptı. Bu tek Tanrının Baba, Oğul ve Kutsal Ruh vasıtasıyla bizi, doğru yola ilettiğine inanırı ${ }^{40}$.

Bir insanının ruhunun ve bedeninin bir insan olması gibi, Tanrı'nın Kelamı'nın ve Hz. Meryem'in ruhunun ve bedenin de bir insan, Mesih olduğuna inanırız. Bunlar ruh ve bedenin birbirinden ayrı olması gibi birbirlerinden ayrıdırlar. Biri diğerine dönüşmemiştir. Ondan Tanrı'nın Sözü tam söz ve insanlığı, tam insanlık olarak vardır. Mesih'in insanlığı Tanrı haline almamış ancak, Tanrı'nın Kelimesi, onun içindeki insan doğasını almıştır. Tanrı'da olan ve doğası gereği tanrısal olan, Tanrı'dır. Bunlar Tanrı' da arizi değildir. Tanrının sözü Tanrı, bu söz de Mesih olduğu için Mesih de tanrı ve insandır. Tanrı'nın Sözü, sonsuz ve her yerde olduğu için İsa ve Baba Tanrı'dadır. İsa, Baba gibi sonsuz güce sahiptir, ancak onun bulunuş biçimleri birbirinden farklıdır. Tanrı hilmini ve sevgisini insanlardan bazısına verir; ancak Tanrı'nın Kelam'1, tam olarak İsa'ya gelmiştir. Bu yüzden, mertebelerine uygun olarak verilen diğer peygamberlere göre, İsa'da mahlûka yönelik Tanrı'nın şefkat ve merhameti daha ziyadedir. Birçok sebepten dolay1, kendi isteğiyle İsa çarmıha gerildi ve öldü. Bunlar onun insani yönüyle ilgilidir. Tanrının sözü ise ne çarmıha gerilir ne ölür ne de dirilip, babasının yanına göğe yükselir. İsa ise, göğe yükselmiş ve tekrar geri gelecektir ${ }^{41}$.

İnsanların ruhları ölümsüzdür. Azizlerin ruhları, bozulmamış olarak kalkacaktır. İnanan ve erdemli hayat yaşayanların ruhları cennette; günahkârların ki ise cehennemde olacaktır. Cennet gökte, cehennem ise yeryüzündedir. Azizlerin mutluluğu, bilgide mükemmelleşme ve Tanrı'nın sırlarını görmekten başka bir şey olmayacaktır ${ }^{42}$.

Gennadius, İsa'nın niçin insan bedenine büründüğüne sağlam cevapları olduğunu, ancak söz konusu bu cevaplar dışında Hıristiyanlığın hakiki bir din olduğuna dair yedi delillerinin bulunduğunu söyler. Bunlardan birincisi, Yahudi Peygamberleri,

40 1-6. Paragraflar, Dinçer, 1584 Yılında Karamanlıca Alfabe ile Yazılmış Bir İtikatname”, 6-8; Talasi-Kun, “Gennadius' Confession of Faith”, 30-34; Papadakis, “Gennadius II and Mehmet The Conqueror", 100-103.

41 7-11. Paragraflar; Dinçer, 8-9; Halasi-Kun, 35-36; Papadakis, "Gennadius II and Mehmet The Conqueror",104-105.

42 12. Paragraf, Dinçer, 8; Halasi-Kun, "Gennadius' Confession of Faith, 35; Papadakis, "Gennadius II and Mehmet The Conqueror", 105. 
Pers ve Yunan müneccimleri İsa'nın geleceğine dair kehanetlerde bulunmuşlardır. bunların hepsi büyük ölçüde İsa için uygundur ve bunların, inkar edilemezliği kanıtlanır. İkincisi, Hıristiyan kutsal metinleri birbiriyle uyumludur. Onların ileri sürdükleri bu kehanetlerin sebebi de hepsinin Tanrı'nın inayeti olan tek bir öğretmeninin olmasıdır. Eğer öyle olmasaydı, birbirleri çatışma halinde olurlardı. Üçüncüsü yeni ve garip olan bu dini, rağbet ve sevgiyle her yerdeki putperest ve ateşperestler kabul ettiler. Bunlar, sadece sıradan insanlar değil, âlimler ve hakimlerdi de; bu yüzden çok fazla zahmet çektiler. Dördüncüsü bu dinde imkânsız, maddi, tutarız olan hiçbir şey yoktur. Her şey manevidir ve Tanrının sevgisini iletir. Beşincisi, bu inancı kabul edenler ve İsa'nın yaşamına uygun erdemli hayat yaşayanlar, Tanrı'dan büyük lütuflar elde ettiler ve İsa adına, büyük mucizeler icra ettiler. Eğer Hıristiyanlık hak din olmasaydı, böyle olmazdı. Altıncısı, bu dinin aleyhine ileri sürülecek her şeye, cevap verebiliriz, yedinci ise, 318 yıl boyuncu çok tanrıya ve putlara tapan krallar bu dini savaşarak ortadan kaldırmaya çalıştılar ancak buna rağmen, kuvvetlenip şimdiye kadar geldi. Bu da onun Tanrı'nın rızasına uygun olduğunu gösterir ${ }^{43}$.

İçeriğini özetle zikrettiğimiz bu metnin ortaya çıkmasına yol açan tartışmaların gerçekleştiği ziyaretlerin 1454'ün başlarında ya da 1456'nın ilkbaharında ${ }^{44}, 1455$ ya da 1456 'nın başlarında ${ }^{45}$ gerçekleştiği ileri sürülmektedir. Ancak biz bu iki tarihin de Risâle'den hareketle şu sebeplerden dolayı doğru olmadığını düşünüyoruz:

Birincisi: Risâle'de yazılış tarihi olarak 959/1454/55 verilmiştir.

İkincisi: Üç bölüme ayrılan Risâle'nin birinci bölümünün “Müslümanlarla Hıristiyanlar arasındaki tartışmalar ve Hıristiyanların ilmî ve avâmî soruları ve bunlara verilecek cevaplar hakkında" olmasıdır ${ }^{46}$.

Üçüncüsü: Bu bölümde, “dönemin hakanının” huzurunda olan bir tartışmanın nasıl yürütülmesi gerektiğine dair kuralların yazar tarafından zikredilmesidir: "Bil ki Hakan`ın huzurunda (...) Hıristiyanlarla tartışmada esas (...); sonra onlarla tartışma iki şekildedir $(\ldots)^{47}$.

43 13-20. Paragraflar; Dinçer, 9-10; Halasi-Kun, "Gennadius' Confession of Faith” 35-37; Papadakis, “Gennadius' Confession of Faith”, 105-106. Gennadius'un verdiği bu ifadesi, Konstantin tarafından 312'de ilan edilen ve Hıristiyanlığın devlet tarafından tanınmış dinler kategorisine dahil ettiği, Milan Fermanı'na gönderme yapmaktadır. Ancak verdiği tarih, şimdilerde kabul edilen, fermanın ilan tarihiyle çelişmektedir.

44 Halasi-Kun, "Gennadius' Confession of Faith”, 5.

45 Papadakis, "Gennadius II and Mehmet The Conqueror", 95.

46 Fransa 4b; Leiden $3 a b$.

47 Fransa 4b-5a; Leiden 3b-4a. 
Dördüncüsü ise: yazar ana kaynak olarak kullandığg Risâlütü'n-Nâsıriyye'nin ${ }^{48}$ bölümlenmesini aynı şekilde takip etmeyip onda üçüncü bölümde yer alan, Hıristiyanlarla zamanın hakanının huzurunda yapılacak tartışma ve bu tartışmanın usullerini kendi risalesinde birinci bölüme çekmiş olmasıdır ${ }^{49}$.

Risâle'nin yazılış tarihi, adına yazıldı̆̆ı kişi, zamanın hakanının huzurunda yapılan Müslüman Hıristiyan münazarasının zikredilmesi bütün bunlar, Risâle'nin Fatih-Gennadius arasında gerçekleşen dini diyalogla olan ilişkisini neredeyse kesin olarak ortaya koymaktadır.

Ancak İslam ve Müslümanlara yönelik herhangi bir eleştirinin yer almadığı, tamamen Ortodoks Hıristiyanlığ anlamaya yönelik bir konuşma ve onun inanç esaslarını anlatmaya yönelik bir metin böyle bir reddiyeyi hak etmekte midir?

Risale'nin muhtevasıyla İtikadnâme'ninki karşılaştırıldığında, konuşmanın gerçekleşme tarzının ve İtikadnâme'de yer alan Ortodoks inançlarının ve bu inançların anlatım biçimlerinin onun yazılmasına yol açtı̆̆ söylenebilir.

Görüşmenin cereyan ediş tarzı, “zamanımız Hakan'ın huzurunda”, münazaranın nasıl olması gerektiğine dair ifade hem Fatih hem de katılanların nazarında görüşmenin usulüne uygun olmadığına dair bir hissin uyanmasına yol açmış olduğunu gösterir. Dolayısıyla da muzaffer hakanın huzurunda yapılacak olan bir tartışmanın, konuşmanın nasıl olması gerektiğinin hatırlatılmasına ihtiyaç duyulmuş olmalıdır.

Her ne kadar konuşma sırasında ve metnin kendisinde İslam'a ve Müslümanlara yönelik herhangi bir eleştiri ya da aşağılayıcı bir ifadeye yer verilmemiş olsa da İtikadnâme'nin yukarıda zikredilen ve özet olarak verilen konuları dikkate alındığında, onda Hz. Peygamberin peygamberliğine ve Müslümanların İslam dini hakkındaki iddialarına yönelik meydan okumaların yer aldığı açıkça görülecektir. $\mathrm{Bu}$ iddiamızı temellendirmek adına bunlardan birkaç tanesi zikredebilir:

Birincisi Gennadius'un metnine koyduğu başl1ktır: "İnsanlığın Kurtuluşu İçin Yegâne Yol”. İslam'ın en önemli iddialarından biri, kendisinden önceki dinlerin artık geçerliliklerini yitirdikleri ve Allah katında, doğru yola götüren yegâne dinin İslam olduğu şeklindedir ${ }^{50}$. Gennadius'un başlığ 1 bu geçerlilik yitirme (nesh edilme) ve yegânelik iddiasına açık bir meydan okumadır. Bu meydan okumaya yönelik olarak Risâle, İslam'ın kendisinden öncekileri neshettiği meselesini hemen birinci bölümde ele almaktadır ${ }^{51}$.

48 Zâhidî, Risâlütü'n-Nâstriyye, 45-75.

49 Fransa 8b vd.; Leiden 3b-42b.

50 Al-i İmrân 3/19, 83, 85.

51 Fransa 6-7 vd.; Leiden 5-6. 
İkincisi, Tanrı anlayışlarının teslis olmasına rağmen, Tanrının tek olduğuna ve İsa'nın Tanrı'nın Kelamı'nın kendisinde beden bulduğu, çarmıhta öldüğü, gömüldüğü ve dirilip babasının yanına yükseldiğine dair ifadeleridir.

Hıristiyanların İsa'nın beden bulmuş tanrı olarak içinde yer aldığ 1 teslis inancı ve çarmı meselesi İslam'ın Hıristiyanlığa yönelik en önemli eleştiri konularından biridir. Kur' an bu inançları çok sert bir biçimde eleştirdiği gibi bu iki konu, daha sonra hem kelam ve hem de Hıristiyanlık karşııtı metinlerin temel konuları arasında yer almaktadir ${ }^{52}$.

İncillerin birbirleri arasında herhangi bir tenakuzun bulunmadığı, bunların Tanrı'nın inayetiyle yazıldığg ifadeleri de Hz. Peygamberin peygamberliği ve Müslümanların İslam dini hakkındaki iddialarına yönelik meydan okumaların açıkça yer aldığına dair iddiamızı desteklemektedir. Zira, Hz. Peygamberden beri Müslümanların Hıristiyan İncillerinin otantikliği ve ilahi oluşu hususunda ciddi kaygıları vardır. Hıristiyanlık karşıtı İslam reddiye geleneğinin en hararetli konularından biri, birden fazla İncil'in olması ve bunların birbirleriyle telif edilemez tutarsızlıklar içermesidir ${ }^{53}$.

Hz. İsa'nın çok büyük mucizeler göstermesinin dile getirilmesine gelince; bu yalnızca Hz. İsa'nın peygamberliği bağlamında söylenmiş bir söz olsaydı Risâle yazarının buna pek bir itirazı olmazdı. Ancak, İslam karşıtı metin kaleme alan Yuhannaed-Dimeşki ${ }^{54}$ de dahil diğer bütün Bizans kökenli eleştirmenler ${ }^{55}, \mathrm{~Hz}$. Peygamberin, Kur'an'ın tanıklı̆̆ıyla ${ }^{56}$ mucize göstermediği için hakiki peygamber olamayacağını iddia ederler ${ }^{57}$. Bu arka plan dikkate alındığında, İsa'nın mucizelerinin öne çıkarılmasının da bir meydan okuma olduğu söylenebilir.

Yahudi peygamberlerinin Hz. İsa'nın gerçekleştirdiklerinin hepsini önceden haber vermeleri, Yunan kahinlerinin, Pers ve Yunan müneccimlerinin bir takım kehanetlerde bulundukları ve bunların hepsinin İsa için uygun olduğu iddiası da

52 Bakara 2/116; Nisâ 4/171; Mâide 5/17, 72-73, 116 Enâm 6/101; Tevbe 9/30-31; Meryem 16/35.

53 İnciller hakkındaki klasik dönem eleştirileri için bk. Aydın, Müslümanların Hıristiyanlara Karşı Yazdıkları Reddiyeler ve Tartışma Konuları (Ankara: TDV Yayınları, 1998).

54 Yuhannaed-Dimeşkî için bk. İsmail Taşpınar, "Doğunun Son Kilise Babası Yuhanna ed-Dimaşkî (649-749) ve İslam”, M. Ü. İlahiyat Fakültesi Dergisi 21 no. 2 (2001): 23/54.

55 John Meyendorff, "Bizans'ın İslam Anlayışı”, çev. Fuat Aydın, Sakarya Üniversitesi İlahiyat Fakültesi Dergisi 4 no 6 (Aralık 2002): 21-46.

56 En'âm 6/37, “Ona, rabbinden bir mucize indirilseydi ya!”, dediler. De ki: Şüphesiz Allah mucize indirmeye kâdirdir. Fakat onların çoğu bilmezler".

57 Hıristiyanların bu iddiaları için bk. Fuat Aydın, Batı İslam Algısının Arkeolojisi (Ankara: Eskiyeni Yayınlar1, 2011), 39-40. 
böyledir. Keza bu da yine, Hz. Muhammed'in peygamber olmadığ çünkü diğer peygamberlerin önceden haber verildiği gibi Muhammed'in bu şekilde geleceği önceden haber verilmemiştir. ${ }^{58}$. İtikadnâme'nin bu iddialarına karşı1ık Risâle yazarı ise Hz. Peygamberin çok sayıda mucize gösterdiğini hem de Yahudi ve Hıristiyan kutsal kitapları tarafından önceden haber verildiğine yönelik atıflarda bulunmaktadır.

Son bir örnek olarak Hz. İsa'nın insanlara yönelik merhametinin ve şefkatinin çok yüksek olduğu iddiası zikredilebilir. Risâle yazarı bunun örnekleri olmak üzere, mucize bahsinde Hz. Peygamberin hastaları iyileştirmesine, görmeyen gözleri görür hale getirmesine ve ölüleri diriltmesini kaydeder.

Özetle, Risâle'nin yazılma sebebi, Fatih-Gennadius konuşması ve bu konuşmalar bağlamında Gennadius'un Ortodoks Hıristiyan inancını özet olarak anlattığı metnidir. Tartışmada Gennadius'un tavrı ve metninde Ortodoks Hıristiyan inanç esasları olarak zikrettiği hususlar, Müslümanların kendileri ve Hıristiyanlık hakkındaki iddialarına bir meydan okuma gerçekleştirmiş ve Sultan bundan rahatsız olmuştur. Bunun üzerine, kendisiyle beraber bu konuşmalara katılanlardan biri olan yazardan, çok kısa bir süre içinde, konuşmalarda ve İtikadname'de ortaya konulan inanç esaslarını Müslümanların bakış açısıyla değerlendiren, İslam'a yönelik meydan okumaları cevaplandıran bir metni kaleme almasını istemiştir.

\section{Risâle'nin İçeriği}

Risâle bir giriş ve üç bölüm halinde düzenlenmiştir ${ }^{59}$.

Girişte Allah'a hamd ve onun resulüne yönelik dualardan sonra, Âl-i Osman'dan Murad Han oğlu Sultan Muhammed'in adının daim olması için bu risaleyi onun adına yazmayı ve onda Hanîf dinin delillerini ve onun hakkında gizli ve açık ileri sürülen soruları cevaplamayı istediğini söyler.

Birinci bölüm, Müslümanlarla Hıristiyanlar arasındaki tartışmaya ve Hıristiyanların ilmî ve avâmî soruları ve bunlara verilecek cevaplarına; ikinci

58 Hz. Peygamberin Yahudi ve Hıristiyan kutsal kitaplarında vaat edildiğine dair ayetler için bk. Bakara 2/146, En'âm 6/20; A'râf 7/157; Saff 61/6. Yahudi ve Hıristiyanlık karşıtı reddiyelerin en temel konularından birini (tebşînât) oluşturduğu gibi, bu konuyla alakalı müstakil metinler de kaleme alınmıştır. Bunlardan bize kadar gelen en eski metin 865 'te vefat eden Ali b. Rabben et-Taberî'nin, ed-Dînve'd-devle fî isbâti' $n$-nübüvveadlı kitabıdır. Bu kitabın Türkçe çevirisi için bk. Ali b. Rabben et-Taberi, Hz. Muhammed(sav)'in (Yahudi ve Hiristiyan Kutsal Kitaplarındaki) Peygamberliğinin Delileri, çev. Fuat Aydın (İstanbul: Ensar Yayınları, 2021). Ayrıca Aydın, Müslümanların Hıristiyanlara Karşı Yazdıklart; Fadıl Ayğan, Son Peygamberi Müjdelemek, Beşâirü'n-Nübüvve (Ankara: TDV. Yayınları, 2017).

59 Fransa 4b; Leiden $3 a b$. 
bölüm, Muhammed (as)'ın peygamberliğinin hak olduğuna dair deliller ve onun mucizelerinin bir kısmının zikrine; üçüncü bölüm ise, Onun peygamberliğine karşı çıkanlar(muhalifler) ve onların şüphelerine yönelik cevaplara dairdir.

Birinci bölüm başlığı zikretmeksizin ve Hakan'ın huzurunda Hıristiyanlarla Müslümanlar arasındaki tartı̧̧mada, tartışmanın Hıristiyanların anlayabilecekleri şekilde yapılmasını, anlaşılması zor ifade ve kavramların kullanılmaması gerektiğini söyleyerek başlar. Bu tür bir tartışmanın iki şekilde yapılması gerekir. Birincisinde Hıristiyanların sorularını sormaları ve Müslümanların sorulan sorulara, sorunun yapısına uygun olarak Bâkıllânî’nin Bizans sarayında rahiplerle tartışmasında yaptı̆̆ gibi, tahkik türü sorulara, tahkiki cevaplar; cedeli sorulara ise cedeli cevaplar verilmesi gerekir.

İkinci usul, Müslümanların şöyle diyerek başlamalarıdır: Allah kullarına bir zamanda tebliğ ettiği hükümleri, hikmet ve iradesine uygun olarak değiştirmiştir. Mucizelerin doğruluklarına tanıklık ettiği Allah'ın gönderdiği peygamberlerle öncekilerden uzun zaman geçtikten sonra faklı zaman ve olaylar bağlamında önceki haramlarda ve helallerde değişiklik yapmak, O'nun tarzıdır. Allah'ın bunun için çok sayıda peygamber gönderdiği herkes tarafından kabul edilir. Hakanlar ve valiler de böyle yaparlar, daha önce verdikleri hükümleri değiştirdikleri gibi, bunları gönderdikleri elçilerini değiştirirler ve onların ellerine bu değişikliklerin bulunduğu mektuplar verirler.

Biz peygamberler ve onların mucizelerini bizatihi görmedik, onlar hakkındaki bilgiler bize tevatür yoluyla gelmiştir. Eğer onlar hakkındaki bu tevatürle nakil kabul edilmeyecekse hiçbir şey hakkında da kabul edilmemesi gerekir. Yakın zaman hakkındaki bilgiler, uzaktakilere göre daha çok kabul edilirdir. Hz. Peygamber hakkındaki bilgiler diğerlerine nazaran daha yakın olduğu için, kabule daha şayandırlar. Önceki peygamberler başkası gelinceye kadar kendi zamanlarında hak oldukları gibi, Hz. Peygamber de şimdi ve gelecek zamanlar için de gerçek peygamberlerdir.

Bu girişten sonra yazar, Hıristiyanların Müslümanlara yönelik çok sayıda sorusunun olduğunu ve bunun da ilmi ve avami olmak üzere iki gruba ayrıldığını söyler. Bu sorular toplam kırk tanedir. Yazar bunları teker teker zikredip, hemen arkasından da cevaplarını vereceğini söyler. Ancak bunlardan otuz beş tanesine yer verir. Bu soruların bir kısmı, Hz. Peygamberin İslam'1 getirmesiyle kendisinden önceki Yahudilik ve Hıristiyanlığı geçersiz kıldığına (nesh ettiğine), oysa Musa ve İsa'nın böyle yapmadığına; geri kalan soruların önemli bir kısmı Hz. İsa'nın Hz. Peygamber'den üstün olduğuna (İsa diri, Muhammed ölü; İsa ilahi kökene sahiptir; dünya kadınlarının hanımefendisinden doğmuş̧tur, Muhammed necis bir nufeden; Allah İsa ile birleşmiştir, Muhammed'le değil; İsa uknûmların 
ikincisi, oğuldur, Muhammed değildir; İsa Allah tarafından müjdelenmiştir; İsa bebekken ilah olduğunu söyledi, Muhammed söylemedi; İsa hevâsına tabi olup evlenmedi, mucizeleri gerçektir, Muhammed'in ki sihirdir; İsa insan öldürmeyi ve yağmayı getirmedi; İsa hoşlanmadığı şeylere karşı sabırlıdır; İsa başta da sonda da peygamberdir; Muhammed Allah tarafından azarlanmıştır, İsa iki kitap-şeriat sahibidir; Muhammed ümmi, İsa okuryazardır; İsa baş, Muhammed ayaktır; Muhammed'in şeriatinde aklın almadığı şeyler vardır, çok az bir kısmı da, Hz. Peygamberin peygamber olmadığı, geri kalanlar ise O’nun yalnızca Araplara gönderilen bir peygamber olduğuna (kavminin diliyle gönderilmesi, Arapların ümmi olup kitaba ihtiyaçlarının olduğu, ehli kitabın kitapları olduğu) dair soru şeklinde dile getirilmiş iddialardan oluşmaktadır. Yazar bunların her birinin usul olarak ortaya koyduğu şeye uygun olarak teker teker zikreder ve sonra onları çeşitli vecihlerden olmak üzere hem akıl yürütme hem de Yahudi ve Hıristiyan kutsal kitaplarından hem de Kur'an'dan getirdiği nakli delillerle, örneklerle cevaplamaya çalışır ${ }^{60}$.

Hz. Peygamberin peygamberliğinin gerçekliği ve mucizeleri hakkında olan ikinci bölüme, O’nun gerçek bir resûl olduğunu söyleyerek başlar. O, her ırktan insana ve cinlere gönderilmiştir. $\mathrm{O}$, bu peygamberliğinin kıyamete kadar geçerli olduğunu iddia etmiş̧ir. Bir insan peygamberlik iddia eder ve hemen arkasından mucize gerçekleștirirse bu onun hak bir resûl olduğuna bir delildir. Yazar, Hz. Peygamberin peygamberliğini bilme hususunda insanların üç gruba ayrıldığını söyler. Bunlardan birincisi, kitapların ve peygamberlerin haber vermesiyle onu tanıyanlar ki bunlar ehl-i kitaptır. İkincisi onun mucizelerini görerek onu tanıyanlardır, bunlar da "Haremeyn" ehlidir. Üçüncüsü ise, onun peygamberlik iddiasını ve mucizelerini tevatür yoluyla bilenlerdir. Bunlar da Haremeyn ehlinin neslinden kiyamete kadar gelecek olanlardır. Hz. Peygamberi bilme hususunda bizim için gerekli olan iki şey, tevatür ve düşünmedir. Bunlardan biri olmazsa onun peygamberliğini bilemeyiz. Tevatüre, akılla anlaşılmayan, Hz. Peygamberin ölümü, insanlara ve cinlere peygamber gönderilişi ve mucizelerin gerçekleştiğini bilmek için ihtiyaç vardır. Allah'ın yalancı birini teyit etmek için peygamberlerin şahsında mucize göstermenin buna vesile olamayacağını bilmede de aklî düşünceye ihtiyaç vardır. Yazara göre akıl, yukarıda zikredilen yollarla Hz. Peygamberi bilen üç kesim için de ortak, tevatür ise sadece ümmetinden onu araştıranların hakkındır.

Hz. Peygamberden mucizelerin zuhur ettiğine dair delilin ne olduğu sorusuna, buna mucizeler iki kısımdır diyerek cevap vermeye başlar. Biri geçmişte olan ve varlığı hala devam edenler: İnsanların benzerini getirmekten aciz oldukları Kur'an gibi, ikincisi ise geçmişte olup orada kalanlardır.

Fransa 4b-43a; Leiden 7a-42a-b. 
Peygamberin mucizeleri iki kısımdır, birincisi irhasi olanlar ikincisi ise tasdiki olanlar.

İrhasi olanlar onun peygamberliğinden önce ve ona hazırlık olarak gerçekleşenlerdir: Nur-1 Muhammedi, sünnetli ve avret mahallini eliyle örterek doğması; doğduğu gece Arap ve Acem diyarındaki putların yere düşmeleri; Pers ve Rum kayserinin saray burçlarının yıkılması; nübüvvet mührünün bulunması; bulutların üzerinde gölge olması gibi. Tasdiki olanlar ise biri zatı hakkında diğeri zatının dışında olmak üzere ikiye ayrılır. Zatıyla ilgili olanlar, önünü ve arkasını görmesi; omuzlarının arasında iki gözünün olması; uzunun yanında uzun, orta boylunun yanında da orta boylu görünmesi; asla yalan söylememiş olmasi; emin olarak isimlendirilmiş olması; hiçbir zaman düşmanlarından kaçmayacak kadar cesur olması; nihayetsiz merhamet sahibi olması; dünyaya karşı zahit tavrı göstermesi; üstün bir ahlaka sahip olması; servete tepeden bakarken yoksul ve miskinlere karş1 mütevazı olması ve en üst düzeyde sabırlı olmasıdır.

Zatının dışında gerçekleşen tasdiki mucizeleri ise ayın yarılması; çağırması üzerine ağacın gelmesi; taşların ona selam vermesi; hurma kütüğünün inlemesi; parmaklarının arasından suların kaynaması; susuz kuyuyu suyla doldurması; az yiyecekle çok kişiyi doyurması, zehirli koyunun; zehirli olduğunu kendisine haber vermesi ve Ebû Evkâ'nın kızını diriltmesi vs. gibilerdir. Yazar bunların onun mucize denizinden yalnızca bir katre olduğunu, bu kadarının yeteceği için bunlarla sınırladığını söyler.

Kur'an ve bu mucizeler hususunda tevatürü kabul etmeyenlere; Kur'an hakkında üç cihetten tevatür olduğunu söyler. Kur'an hakkındaki tevatür harikuladedir. Fatiha, muavvizateyn vs. hakkındaki tevatür ise dünyanın her yerinde onların Kur'an olarak okunmuş olmasıdır. İkincisi, haberler iki türlüdür. Birincisi lafzın ona uygun olarak getirilmiş olmasıdır. İkincisi, Kur'an mescitte, namazda ve başka yerlerde okunduğunda dinleyenler ondaki herhangi bir değişikliğe itiraz etmeleridir. Okunduğunda sessiz kalmaları okunanın Kur'an olduğunu dair tasdiktir. Üçüncüsü yazı ile haber, örfen konuşarak haber vermek gibidir. Hz. Peygamberin getirdiğinin Kur'an olduğu hususunda ittifak ettiler ${ }^{61}$.

Üçüncü bölüm, Hz. Peygamberin Peygamberliğini kabul etmeyen gruplara ayrılmıştır. Yazar bunları on grup olarak belirler. On gruptan sekiz tanesi, peygamberliğin aslını; iki tanesi, Hz. Peygamberin insanlara ve cinlere gönderilmiş bir peygamber oluşunu inkâr ederler. Burada yazar, bu grupların peygamberliğin aslıyla alakalı iddialarını zikrederek (son iki grubu ele almaz) bunları cevaplandırır.

61 Fransa 43a-58a; Leiden 42b-58a. 
Birinci grup, peygamberlerin gönderilmesinden maksadın, ümmetlerini mükellef kılmak olduğunu iddia ettiler. Ve mükellef kılma sözünün geçersiz; mükellef kılanı tekliften müstağni kıldığı için zararlı olduğunu; zararlı olan bir şeyle mükellef k1lmanın ise çirkin olduğunu, söylediler.

İkinci gruptakiler, teklifi kabul etmekle birlikte aklın yeterli olduğunu, onun iyiyi ve kötüyü ayırt edip, iyiyi yerine getireceğini ve şüpheli şeylerden de kaçınacağını iddia emektedir. Üçüncü grup, peygamber göndermenin aklen caiz olduğunu, bunun için yegâne delilin mucize olduğunu, onun da sihre benzediğini ve sihrin de güvenilmez olduğunu iddia edenlerdir. Buna karşılık olmak üzere, sihir öğretmen-öğrenci ilişkisiyle olur; sihir bilgiyle gerçekleşir, oysa sihir gerçek bilgiyi sunmamaktadır, mucizede ise durum böyle değildir, der. Dördüncü grup mucize adetten sapmadır ve bu mümkün değildir demelerine karşılık, adeti yaratan da Allah olduğu için, peygamberini tasdik için onu kaldırması mümkündür, der. Beşinci grubun, bizim mucizelere tanık olmadığımızı, onların tevatür yoluyla bize kadar geldiğini, bunun ise sadece bir haberden ibaret olabileceğini, ilim ifade etmeyeceği iddiasını taşıdıklarını ifade eder. Bu grubun bu iddiasına karşılık, görmediğimiz ülkeler ve geçmiş sultanlar hakkındaki bilgilerimizin de tevatüre dayandığını ve bunların ilim ifade ettiğini söyleyerek cevap verir. Sûfiyeden olan altıncı grup, Allah'tan başkasıyla meşgul olmanın Allah'tan alıkoyduğunu; peygamberlerin de ibadet ve çeşitli emirlerle insanları meşgul ettiklerini, bu yüzden peygamber gönderilmesinin doğru olmadığını ileri sürerler. Buna, ibadetle ve emirlerle meşgul olmanın Allah'la meşgul olmak olduğu; dünyevi şeylerin yol açtığı meşguliyetten alıkoymak için, hidayet yolunu göstermek için peygamber gönderilmiştir, diye cevap verir. Yedinci gruptakiler, Şeriatta hac, umre, namaz vs. gibi saçma şeyler vardır, derler. Buna ise, bazı cahillerin ortaya koydukları tavırları dikkate alarak böyle bir şey söylenemeyeceğini, onların akıl sahiplerinin vakıf oldukları çok fazla faydalarının olduğu, şeklinde cevaplandırır. Yazar, bir diğer grup olarak, sekizinci grubun iddialarını dile getirmektedir. Bu iddiaya göre peygamberler dünya menfaatleri ve ortaya çıkabilecek fitnelerini teskin etmeleri için gönderilmişlerdir; ancak birtakım bilginler, yöneticiler ve doktorlar bunların bilgisine sahip olabilmekte ve onları engelleyebilmektedirler. Dolayısıyla bu grubun iddialarına göre onlara ihtiyaç bulunmamaktadır. Bu grubun bu iddialarının tutarsızlığının da helal-haram ve güzel-çirkinin bilinmesinin Allah'ın razı olması, kızması ve saadete götürmesi hususunda temel olduğunu; bunların da ancak peygamberler aracılığıyla bilinebileceğini söylemekle cevaplamaya çalışır.

Yazar bu üçüncü kısmın on gruptan oluştuğunu söylemekle birlikte bunlardan yalnızca sekizini zikreder. Bundan dolayı da Thomas'ın söylediği gibi metin bu haliyle noksan görünmektedir. Ancak yazar ana kaynak olarak kullandığg Risâletü'n- 
Nâstriyye'de on iki olarak belirttiği peygamberliğin muhaliflerini on grup olarak zikreder, son ikisine ise yer vermez. Risâle'mizin yazarı da onu bire bir takip ederek onun fiilen yer verdiği on gruba zikreder. Ancak dokuzuncu ve onuncu grupların itirazları olarak zikrettiği: Hz. Peygamberin kendisinden önceki şeriatleri neshettiğini ve bunun da bedâ anlamına geldiği, onun da Allah'a yakışmayacağı ve Hz. Peygamberin İsmail oğullarına gönderildiği şeklindeki itirazları birinci bölüme taşır. Buna rağmen sayıyı düşürmez, yine on gruba yer vereceğini söylemeye devam eder. Bu da doğal olarak metnin noksan görünmesine yol açar. Buradakine benzer bir şekilde mümkün olmayan bir başka eksiklik ise, yazarın Hıristiyanların kırk sorularının bulunduğu söylemesine rağmen, onlardan yalnızca otuz beşini zikretmesidir ${ }^{62}$.

\section{Risâlenin kaynağı ve kullanma biçimi}

Yukarıda da yer yer ifade ettiğimiz gibi Risâle'nin temel kaynağı, daha çok Zâhidî olarak bilinen, Ebû'r-Recâ Necmeddin Muhtar b. Mahmud b. Muhammed ez-Zâhidî el-Gazmînî (ö. 658/1260)'nin kaleme aldığı er-Risâletü'n-Nâstriyye eseridir. Mutezilî Hanefi fakihi olarak bilinen Zâhidî, eğitimini tamamladıktan sonra Bağdat'a gitmiş, daha sonra Anadolu'ya geçmiş; Karamanoğulları'nın idaresi altındaki Lâren'de de kalmış, ilmi birikimi ve konuları anlatım tarzından dolayı halk nezdinde önemli bir itibar kazanmıştır. Anadolu'nun birçok yerinde ve içlerinde Şeyh Edebâli'nin de yer aldığ birçok kişiye ders okutmuştur. Zâhidî, mezkûr risalesini tamamladığ 3 Haziran 1260'ta Harizm'in merkezi Curcân'da vefat etmiştir ${ }^{63}$.

Zâhidî, Risâletü'n-Nâsıriyye'sini, giriş kısmında açıkça görüleceği üzere, Altın Orda Devleti’nin ilk Müslüman yöneticisi olan Berke Han adına kaleme almıştır.

Zâhidî’nin Risâletü'-Nâstriyye'yi yazma sebebine gelince: 1240'lardan itibaren Moğolları Hıristiyanlığa döndürmeye yönelik çabaların olduğunu biliyoruz. Hatta batıda Moğol prenslerinin Hıristiyan olduklarına yönelik sözler bile yayılmaya başlamıştı. Bu da Ortodoks Nastûrîler ve Yakûbîler kadar Katolik kökenli Dominiken ve Fransisken tarikat mensuplarının da misyonerlik faaliyetlerinin yönünü Asya'ya çevirmelerine yol açmıştı. Bunun bir sonucu olarak da Hıristiyan misyonerlerinin Moğolları Hıristiyanlaştırmaya yönelik çabalarını arttırmaya başladıkları ve bu hususta yöneticilerle görüşmeler yaptıkları ve onların huzurunda dini tartışmalara katıldıkları görülmektedir ${ }^{64}$.

62 Fransa 58a-63b; Leiden 58b-63b.

63 Zâhidî’nin hayatı ve eserleri hakkında bk. Şükrü Özen, "Zâhidî”, TDV İslam Ansiklopedisi, Ankara: TDV Yayınları, 2013, 44:81-85.

64 Benzer bir durumun İlhanlı Moğolları için de söz konusu olduğu söylenebilir. Hatta İbnKemmûne'ninTenkîhü'l-ebhâs adlı eserinin böyle bir bağlamda, Yahudiliğin Hıristiyanlıktan ve İslam'dan üstün olduğunu göstermeye yönelik bir maksatla yazıldığı söylenebilir. Böyle bir okuma için bk. Fuat Aydın, “İbnKemmûne ve Tenkîhu'l-ebhâsli’l-mileli s-selâs üzerine”, F. Aydın-Y. Meral, F.B. Taş, İbnKemmûne ve Tenkîhü'l-ebhâsli'l-mileli s-selâs Üzerine Araştırmalar (Ankara: Eskiyeni Yayınları, 2021), 40-54. 
Oraya ne zaman geldiği kesin olarak bilinmese de Altın Orda'nın hakimiyeti altındaki Harezm'de yaşayan Zâhidî'nin Risâle'sindeki ifadesinden devlet sarayında ve idarecilerin huzurunda, farklı din mensuplarının katıldığ 1 dini tartışmaların yaşandığ ve hatta bu tartışmaların 1256'da tahta geçen ve tahta geçmeden önce Müslüman olduğu kabul edilen Berke Han zamanında da devam ettiğini anliyoruz.

Zâhidî’nin risâlesini bu dini tartışmaların devam ettiği bir bağlamda; Berke Han'ın yanında bulunup İslam adına tartışmaya katılanlara malzeme sağlamak maksadıyla yazmış olduğu anlaşılmaktadır. Bunun böyle olduğu, Risâletü'nNâsıriyye'nin, "Yardım Eden/Yardımcı Risâle" anlamına gelen başlığından ve içeriğinden açıkça anlaşılmaktadır.

Risâletü'n-Nâsıriyye'den bahseden en eski kaynak, Kâtip Çelebî'nin Keş̧u'zzünûn'udur ${ }^{65}$. Modern dönemde ilk olarak Steinschneider onu iki farklı isimle; erRisâletü'n-Nâsiriyye ve Risâletün fi'l-munâzara beyne'l-müslimîn ve'n-nasârâ (ve zikri usûletihim) adlarıyla zikreder ${ }^{66}$. Günümüze kadar gelen tek nüshası, şimdilerde Şam Mektebütü'l-Esedi'l-vataniyye olan, el-Mektebetü'l-osmâniyye'de, 187 numarada 1-212 arasında kayıtlı bulunmaktadır. Bu nüsha, Muhammed el-Mısrî tarafından 1994'te tahkikli olarak neşredilmiştir ${ }^{67}$.

İsimsiz Risâle'nin, içeriğinde ve başlıklandırmada ana yapıyı bozmayacak birtakım değişikliklerle Risâletü' $n$-Nâsıriyye'nin iktibas ettiğini söylediğimiz ve yukarıda onun içeriğini nispeten geniş bir şekilde verdiğimiz için burada farkl11ıkların görülmesi için, Risâletü'n-Nâsıriyye'nin giriş içeriği, bölümleme sırası ve başlıklarıyla Risâle'ninki peş peşe yer verilecektir.

Giriş kısmı, Allah'a hamd ve Resûl'üne salat ve selamdan sonra, İslam'1 kabul edişiyle Müslümanların yaşadıkları sıkıntıları ortadan kaldırdığı için çok büyük övgülere mazhar kılınan, Risâle'nin mübarek adının daimî olarak anılması için yazıldığı söylenen Berke Han'a ithafla başlar ve er-Risâletü 'n-Nâsıriyye adını verdiği metnini üç bölüme ayırdığını söyler.

65 Kâtip Çelebi, kitabın yazarı, adına yazıldığı kişiden ve içeriğinden söz eder. Keş̧u'z-zunûn fì esâmi'l-kutübve'l-funûn, çev. Rüşdü Balc1 (İstanbul: Tarih Vakfı Yurt Yayınları, 2007), 2:728.

66 Steinschneider, PolemischeundapologetischeLiteratur, 63-64.

67 Necmüddin Muhtâr b. Mahmûd ez-Zâhidî, er-Risâletü'n-Nâsıriyye, thk. Muhammed el-Misrî (Kuveyt: Merkezü'l-mahtûtâtve't-turâsve'l-vesâik, 1414/1994). 
Birinci ${ }^{68}$ bölüm, Muhammed (sav)'in Hak oluşana dair deliller ve onun mucizelerinden bir kısmının zikrine dairdir ${ }^{69}$. Müslümanlar ve Hıristiyanlar arasındaki münazaraya ve onların ilmî ve avamî sorularının zikrine ve onların cevaplarına dairdir $^{70}$. İkinci bölüm, Muhammed (sav)'in peygamberliğinin muhaliflerinin zikrine dairdir ${ }^{71}$. Muhammed sallallâhu aleyhi ve sellemin risâletinin hak olduğu hususundaki deliller ve onun mucizelerinden bir kısmının zikrine dairdir"72. Üçüncü bölüm Müslümanlarla Hıristiyanlar arasındaki münazara ve İslam'a yardıma kendisini adayan kişinin zaferi hakkındadır ${ }^{73}$. O'nun peygamberliğinin muhalifleri ve onların şüphelerinin zikrine dairdir ${ }^{74}$.

\section{Risâletü'n-Nâsıriyye'nin Risâle yazarı tarafından kullanılması}

Risâle'nin yazılış gerekçesini, Fatih-Gennadius tartışması, bu tartışmada yaşananlar, orada ele alınan konular, Ortodoks inancını özetleyen amentünün yazılması; Müslümanların inançları, Hıristiyanlık hakkındaki kabullerine yönelik meydan okumalar içermesi karşısında bunları cevaplanmak maksadıyla, -büyük bir ihtimalle de- Fatih'in talebiyle yazılmış olduğunu yukarıda söylemiştik.

Risâle yazarı, istenilen konuyla alakalı ne yazacağını düşünürken medresede ders kitabı olarak okuduğu Kudûrî şarihi Zâhidi’nin hayatına, eserlerine aşinalığının bir sonucu olarak onun böyle bir risale yazdığını; yazılma bağlamıyla, kendisinden yazılması istenen risalenin bağlamının aynı olduğunu fark etmiş ve onu kullanmaya karar vermiş görünmektedir. Fatih-Gennadius tartışmalarının ve İtikadname'nin 1454 sonu 1455 başı ve onlara karşı yazılmış olan Risâle'nin tarihinin 1455 olması; yazar için araştırma yaparak müstakil bir metin yazmayı mümkün kılacak bir sürenin verilmemiş olduğunu da gösterir. Bu da maksadı gerçekleştirecek nitelikleri haiz bir metnin kaynak olarak kullanılmasını zorunlu hale getirmiş görünmektedir.

Yukarıda zikredilen sebeplerden dolayı Risâle'nin yazarı Zâhîdi'nin metnini kullanmaya karar vermiş; ancak bir kısmı zikredilen değişiklikler yapmış olsa ana yapıyı bütünüyle değiştirmeyerek aynen istinsah etmenin yol açacağı sıkıntıların

68 Burada iki metnin içeriğinin yazarları tarafından verilen bölümlemesi ve içeriğinin karşılaştırılması hedeflenmektedir. Bu yüzden "Birinci bölümden” sonraki ilk cümle, Zâhidî’nin metnin; ikinci cümle ise isimsiz risâle'nin bölümlemesini ifade etmektedir.

Zâhidî, Risâletü'n-Nâsıriyye, 28, 29-40.

70 Risâle, Fransa 4; Leiden 3a-b.

71 Zâhidî, Risâletü'n-Nâsıriyye, 28, 41-46.

72 Risâle, Fransa 4b; Leiden 4b.

73 Zâhidî, Risâletü'n-Nâsıriyye, 28, 46-75.

74 Risâle, Fransa 4b; Leiden 4b. 
da farkındadır. Bu yüzden her şeyden önce Zâhidî’nin metnini tarihsizleştirir. Bunu da Risâtü'n-Nâsıriyye'nin yazarının yaşadığı yeri ve yazıldığı tarihi ifşa edecek tarihler, tarihi şahıslar ve yer ismine yönelik atıfların geçtiği yerlerin bir kısmını istinsah etmeyerek ve istinsahtan kaçınması mümkün olmayanları da kendi yaşadığg 1 döneme yani, Fatih'in zamanına denk gelecek şekilde tarihselleştirerek yapar.

Allah'a ve Resûlü'ne yönelik olan kısmı aynı şekilde bırakır. Risâletü'nNâsıriyye'nin yazar adının yerini genel bir ifadeye “Allah'ın rahmetine muhtaç, fakir, aciz kul”, ifadesi alır. Bu ifade, her ne kadar bir tevazu ifadesi olarak görülse de Fatih'in emri ve isteği karşısında, acziyetini ve istenileni yapmaktan başka bir çaresinin kalmadığının bir ifadesi olarak da okunabilir. Risâlütü'n-Nâsıriyye'nin kendisi için yazıldığı Berke Han'a yönelik övgüler yerini Al-i Osman'dan Sultan Murad Han Oğlu Sultan Muhammed'e bırakır. ${ }^{75}$ İsimsiz yazarımızın Risâle'yi yazma gerekçesi birincil olarak Fatih-Gennadius tartışmasının verdiği rahatsızlık olmalı ki, Zâhidî'nin Hakan'ın huzurunda yapılacak tartışmaya dair usulü zikrettiği üçüncü bölümü, birinci bölüm olarak ileri çektiği gibi, Zâhidî’nin başlığında yine Berke Han'a gönderme yaptı̆̆ı anlaşılan ifadeyi de değiştirir ve bölüm içinde yer verilen sorular ve onlara verilecek cevaplar ifadesini başlığa çeker. Üçüncü bölüme indirdiği ikinci bölümde, Hz. Peygamberin isminin yerine zamiri koyarak ifadeyi kısaltır ve "muhalifler"e, "onların şüphelerini zikrine dair" ifadesini ekler.

Zâhidî’nin risalesini yazdığ 1 anda Hz. Peygamber'in zamanından 650/1260 y1 geçti şeklindeki tarihlendirmesini 859/1455 olarak günceller ${ }^{76}$. er-Risâletü'nNâsıriyye yazarının Harezm,Cürcan' da bir Hıristiyan din adamıyla yaptığını söylediği tartışmay1 ${ }^{77}$, yazarın bulunduğu yeri gösterdiği için atlar. İkinci bölümde, Zâhidî İslam'ın muhaliflerinin on iki grup olduğunu söyler ${ }^{78}$. İsimsiz müellifimiz, nesihle ilgili olan son ikisini birinci bölümün başına çektiği için onları on olarak zikreder ancak aşağıda kısmen değineceğimiz üzere sekiz tanesine yer verir ${ }^{79}$.

Zâhidî'nin Emeviler döneminde gerçekleştiğini söyleyerek anlattığı, Vâsıl adlı şeyhin ana kahraman olduğu dini tartışmayı (ki bu tartışma aslında Zâhidî’nin Bâkıllâni’ye atfettiği tartışmanın devamıdır) zikretmeyerek atlar. Bâkıllânî'nin ana karakter olduğu birinci tartışmayı zikrederken aynı niteliğe sahip ikinciyi

75 Zâhidî, Risâletü'n-Nâsıriyye, 27; Risâle, Fransa 2b-3a.

76 "Nübüvvet asrından, bu yana 650 yıl geçti”, Zâhidî, Risâletü'n-Nâsıriyye, 32. "Nübüvvet asrından bu yana 859 yıl geçti”, Risâle, Leiden 47a.

77 “Hıristiyan ulemasından bazılarıyla, Harezm Cürcan' da tartıştım”, Zâhidî, Risâletü'n-Nâsıriyye, 47.

78 Zâhidî, Risâletü'n-Nâsıriyye, 41.

79 Risâle, Fransa 58a-b; Leiden 58a-b. 
atlamasının sebebi, Hıristiyan-Müslüman tartışmasının Bâkı1lânî’nin tarzında olması gerektiğini söylemesi, diğerinin ise bu bağlamda ismen zikredilmemesi olabilir.

Ancak isimsiz yazarın, Zâhidî'nin metnini güncellemeye ve kısmen de olsa kendi damgasını vurmaya yönelik bütün çabasına rağmen metni, tam olarak Fatih dönemine uyarlamış olduğu da söylenemez. Özellikle Fatih'e yönelik övgülerinin bulunduğu giriş kısmında bu çok açıktır. Yazar, Fatih'in Müslüman olmasından önce İslam'ın yaşadığı sıkıntılardan bahseder ve onun Müslüman oluşuyla bütün bu sıkıntılarının ortadan kalktığını ifade eder. Sıradan bir okuyucunun bile hemen fark edeceği üzere, burada dönemin ruhuna uygun olmayan iki şey vardır. Birincisi Fatih, sonradan Müslüman olmamıştır, yüzlerce yıllık geçmişe sahip Müslüman bir aileden gelmektedir. İkincisi bu dönemde İslam ve Müslümanlar sıkıntı içinde değillerdir. Risâle'nin yazıldığı dönemde İslam ve Müslümanlar, Endülüs'teki durumu bir kenara bırakırsak en rahat dönemlerinden birini yaşamaktadırlar. Fatih, Müslümanların yaklaşık sekiz yüzyıllık rüyalarını gerçekleştirmiş Bizans'1 fethetmiştir. Bu fetih, Batı Hıristiyan dünyası için, dünyanın sonun başlangıcı olarak görülmeye başlanmıştır.

Keza üçüncü bölümde peygamberlik karşıtlarının on olduğunu söyler ancak, bunlardan yalnızca sekiz tanesine yer verir. Kaynak olarak kullandığı Risâletü’nNâsıriyye'nin yazarı da benzer bir şeyi yapar. Bu grupların on iki olduğunu söyler, ancak herhangi bir açıklama yapmaksızın on grubu zikreder. Risâle'nin yazarı aslında onun on olarak zikrettiklerinin hepsine, son iki grubun itirazlarını birinci bölüme çekerek yer verir. Ancak bu bölümde sekiz tanesini zikredeceğine dair bir şey söylemez. On iki diyerek on tane zikreden kaynağı gibi, on der sekiz tanesini zikreder. Bu da yukarıda söylediğimiz gibi metnin noksan görünmesine yol açar.

Dolayısıyla yazar, ne kadar yazıldığı döneme yönelik atıflardan arındırarak Risâle'yi güncel kılmaya ve nispeten kendisine mal etmek için gayret göstermiş olsa da, yukarıdaki türden kalıntıları ve tutarsızlıkları tam olarak temizlemekte başarılı olmamıştır.

Ayrıca Zâhidî’nin metninde olan -ve kendisinin de muhafaza ettiği üzereBâkıllânî'nin yaşadığ 1 dönemi Me'mûn dönemi olarak zikreder. Bu yanlışlığ 1 aşikar olan bir bilgidir. Çünkü Me'mûn dokuzuncu yüzyılda (ö.218/833) Bâkıllânî (ö. 403/1013) ise onuncu asrın ortaları ve on birinci asrın başlarında yaşamıştır.

Bütün bunlar, yazarın metni tarihselleştirme üzerinde yoğunlaştığını, ancak zaman darlığı gibi sebeplerden (?) dolayı bunu tam olarak başaramadığ gibi, metin içinde Zâhidî tarafından zikredilen yukarıdaki gibi anakronizmleri de fark edemediğini gösterir. 


\section{Risâle'nin Hıristiyan Karşıtı Reddiye/İslam Savunu Literatürüne Katkısı}

Buraya kadar anlattıklarımızdan, Risâle'nin on üçüncü yüzyılda Zâhidî'ninRisâletü 'n-Nâsırıyye'sinin yapısal değişikliğe uğratılarak, yazarın kendi maksadına ve yazdığı döneme uygun hale getirilmiş bir metin olduğu anlaşılmaktadır. Dolayısıyla bu özelliklere sahip bir metnin, Müslüman-Hıristiyan tartışmalarına yönelik herhangi bir orijinal katkısının olması mümkün değildir. Ancak yine de iki nüshasının bize kadar gelmesi ve bunların on altıncı ve on yedinci yüzyıllara ait olması, Osmanlı öncesi dönemdeki Hıristiyanların İslam'a yönelik eleştirilerini ve Müslümanların bunlara vermeleri gereken cevapları toplu olarak Osmanlı ulemasının gündemine taşımış olmak gibi bir işlevi yerine getirmiş olduğu söylenebilir.

\section{Sonuç}

Yazıldığı dönem sonrasında kullanıldığının bir göstergesi kabul edilecek şekilde, iki nüshasına sahip olduğumuz risale ve yazar ismi taşımayan ancak, 1454 sonu/1455 başında yazılmış olduğu kesin olan Risâle, Osmanlı'nın kuruluşundan Fatih dönemine kadar yazılmış olan yegâne Hıristiyanlık karşıtı metin olsa da -yazıldığı bağlam dikkate alındığında- aslında bir İslam müdafaası olduğu söylenebilir. Risâle, Fatih-Gennadius tartışmaları ve bu tartışmalar sonrasında Padişah'ın patrikten yazmasını istediği Ortodoks İtikadname'sinin oluşturduğu bağlamda kaleme alınmıştır. Muhtemelen Fatih, tartışmalarda ve İtikadnâme'de zikredilen konuların, İslam ve Müslümanların iddialarına meydan okuyan taraflarını fark etmiş ve bundan rahatsız olmuştur. Bunun üzerine maiyetinde yer alan ve kendisiyle bu tartışmalara katılan, Osmanlı ulemasından, Hanefi literatürüne aşina birisini bu meydan okumaya, en kısa sürede cevap vermesini istemiştir. Bu kısa sürede cevap verme isteğinin sebebi ise, muzaffer Fâtihin inancının, nesh ettiği ve yerini aldığ dolayısıyla İslam'ın yegâne hak din, zaferinin de bunun bir teyidi olduğu şeklindeki iddialarının patrik tarafından zımnen ciddi bir eleştiriye tabi tutulmuş olması ve bunun efkâr-1 umumiyede yol açacağı olumsuz duruma en kısa sürede engel olmak istemesi olabilir. Kendisinden istenen metnin yazılması için verilen sürenin darlığ müellifin, araştırma yaparak yeni bir metin kaleme almasını engellemiştir. Bunun üzerine de yukarıda zikredilen literatüre aşinalığından dolayı, ulaşabildiği Zâhidî’nin metnini kullanmaya karar vermiştir. İlk olarak, yazıldığı tarih ve mekânla gönderme yapan, tarih, yer ve tarihsel şahsiyetlere yönelik atıfları ortadan kaldırarak onu tarihsizleştirmiştir. Daha sonra bölümlerinin yerini, kendisinden böyle bir metnin yazılması talebine yol açan bağlama uygun hale getirmek için (üçüncü bölümü birinci bölüm olmak üzere) değiştirmiştir. Bundan sonra da metni on beşinci yüzyıl, tarihsel bağlamına oturtmaya çalışmıştır. Bunun için de Zâhidî’nin kitabını yazdığı hakanın, Berke Hakan'ın isminin yerine, kendi döneminin hakanının, Fatih'in 
ismini ve kitabın yazıldığı zamana denk gelen tarihler koymuş; başlıklar ve metinde kısmi değişiklikler yapmıştır. Ancak, zaman darlığından dolayı olsa gerektir ki, Risâletü' $n$-Nâsıriyye'nin kullanılış biçiminin ele alındığı yerde zikredilen hem bilgisel (İslam'ın yaşadığı sskıntılar ve Fatih'in sonradan Müslüman olması şeklinde anlaşılacak ifadeler gibi) hem de tarihsel tutarsızlıkların (Bâkıllânı'nin yaşadığı zamanı Me'mûn döneminde gösterme) varlığı, söz konusu tarihsizleştirme ve sonra yeniden on beşinci yüzyıl tarihsel bağlamına oturtma çabasında tam başarılı olduğunu söylemek mümkün değildir.

Bütün bu değişikliklere ve kendi damgasını taşıyan kısmi ilaveler dışında, bir başkasının risalesini, aynen istinsah etmenin yükünü taşıyamayacağını ancak, Fatih'in isteğini de yapmak zorunda olduğunun farkında olan şahsiyet sahibi bir âlim olarak yazar, istenileni yapmış ancak, metnin sorumluluğunu, kendisini yazar olarak zikretmeyerek ve ona yeni bir isim de vermeyerek yüklenmekten kaçınmış gibi görünmektedir.

Teşekkür: Muhammed Ali Bağır, Ravza Aydın, Süleyman Akkuş’a metni okudukları için teşekkür ediyorum.

Hakem Değerlendirmesi: Dış bağımsız.

Çıkar Çatışması: Yazar çıkar çatışması bildirmemiştir.

Finansal Destek: Yazar bu çalışma için finansal destek almadığını beyan etmiştir.

Acknowledgement: I would like to thank Muhammed Ali Bağır, Ravza Aydın, Süleyman Akkuş for reading the text.

Peer-review: Externally peer-reviewed.

Conflict of Interest: The author has no conflict of interest to declare.

Grant Support: The author declared that this study has received no grant support.

\section{Kaynakça/References}

Adang, Camilla- Sabina, Schmidtke. Muslim Perceptions and Receptions of the Bible. Atlanta: Lockwood Press, 2019, 327-411.

Adang, Camilla-Schmidtke, Sabina. Contacts And ControversiesbetweenMuslims, Jews and Christians in the Ottoman Empire and Pre-modern Iran. Wurzburg: Orient-Institute, 2016.

Aydın Fuat, “İbn Kemmûne ve Tenkîhu'l-ebhâsli'l-mileli’s-selâs üzerine”, F. Aydın-Y. Meral, F.B. Taş, İbn Kemmûne ve Tenkîhü'l-ebhâsli'l-mileli's-selâs Üzerine Araştırmalar 11-86.Ankara: Eskiyeni Yayınları, 2021.

Aydın, F.- Meral, Y.- Taş, F.B. İbn Kemmûne ve Tenkîhü'l-ebhâsli'l-mileli's-selâs Üzerine Araştırmalar. Ankara: Eskiyeni Yayınları, 2021.

Aydın, Fuat. “İslam Reddiye Geleneği ve Taşköprizâde Ahmed B. Mustafa’nın (968/1561) Risâlesi Üzerine Bir Araştırma”. darülfünun ilahiyat, 3/2 (2020): 299-353. 
Aydın, Fuat. Osmanlı Dönemi Yahudilik Eleştirileri. Ankara: Eskiyeni Yayınları, 2020.

Aydın, Mehmet. Müslümanların Hıristiyanlara Karşı Yazdıkları Reddiyeler ve Tartışma Konuları. Ankara: Türkiye Diyanet Vakfı Yayınları, 1998.

Balivet, Michel, “1392'de Ankara'da İlahiyat Konulu Bir Münazara: Hacı Bayram Veli ve II. Manaul Paleilogos", AnniePralongo (edt.). Bizans, Yapılar, Meydanlar, Yaşamlar. çev. Buket Kitapçı-Bayrı, 239-248. İstanbul: Kitapyayınevi, 2011.

Crusius, Martinis. Turco gracia elibriocto. Basileae: 1584.

Daş, Mustafa. "XIV. Asırda Dinler Arası İletişim: Bizans İmparatoru II. Manuel Palaiologos ve Hacı Bayram Veli'nin Ankara' da Yaptıkları Tartışma”, XI. ve XVIII. Yüzyıllar İslâm-Türk Medeniyeti ve Avrupa Uluslararası Sempozyum=XI. to XVIII. CenturiesIslamic-Turkish Civilization and Europe International Symposium, 24-26 Kasım 2006, 85-92. ” İstanbul, 2006.

Demircan, Hüsnü. “Orhan Gazi ve Gregory Palamas”, Yüksek lisans tezi, Ankara Üniversitesi, 1993.

Dinçer, Fehmi. "1584 Yılında Karamanlıca Alfabe ile Yazılmış Bir İtikatname”. https://www.academia. edu/9548404/Fehmi_Dinçer_1584_yılında_yazılmış_Gennadius_Scholarius_İtikatnamesi erişim tarihi, 21.11.2021.

Doğan, Hatice. Osmanlı Devleti’nde Hahambaşılık Müessesesi. İstanbul: Gözlem Gazetecilik Basın Yayın A.Ş., 2003.

ez-Zâhidî, Necmuddin Muhtar b. Mahmud. er-Risâletü'n-Nâsıriyye. thk. Muhammed el-Misrî, Kuveyt: Merkezu'l-mahtûtâtve't-turâsve'l-vesâik, 1414/1994.

Fritsch, E. Islam und Christentum im Mittelalter. Breslau: Müller und Sefert, 1930.

Görmez, Mehmet. "Hacı Bayram Veli, II. Manuel Palailogos ve Papa XVI: Benedikt, Papa Benedikt’in Konuşmasının Tarihi ve İlmi Değeri Üzerine”. Diyanet Aylık İlmi Dergi, 190, Ekim 2006:1-5.

https://en.wikipedia.org/wiki/Gregory_III_of_Constantinople

İnalcık, Halil. “Orhan (ö. 763/1362)”, TDV İslam Ansiklopedisi. 33: 375-386.Ankara: TDV Yayınları, 2007.

İnci, Salih. “Osmanlı Dönemi Fener Rum Patriklerinin Seçimi”, İstanbul Üniversitesi İlahiyat Fakültesi Dergisi, 53(2015): 9-58.

Karadaş, Cağfer. "Bizans Sarayında Müslüman-Hıristiyan Münazarası: Büveyhi Elçisi Bâkıllânî ile İmparator II. Basileios Arasında Geçen Tartışma”. İslâm Araştırmaları Dergisi, 22(2009):1-35.

Küçük, Abdurrahman Küçük. Ermeni Kilisesi ve Türkler. Ankara: Berikan Yayınevi, 2005.

Özden Mercan. Constructing A Self-Image in the Image of Other: Poltical and Religious Interpretations of Pope Pius II'Letter to Mehmed II (1461). Budapest: MA Thesis, Central European University, 2008.

Pahlitzch, Johannes. "Gregory Palamas", Christian-MuslimRelationship (1350-1500). ed. David Thomas and Alex Mallet, Leiden-Boston: Brill, 2013, 5:101-108.

Pralongo, Annie (edt.). Bizans, Yapılar, Meydanlar, Yaşamlar, çev. Buket Kitapçı-Bayrı. 239-248, İstanbul: Kitapyayınevi, 2011.

Runciman, Steven. Konstantiniyye Düşü̈. çev. Derin Türkömer, İstanbul: Milliyet Yayınları, 1972.

Runciman, Steven, The Last Byzantine Renaissance. Cambridge: Cambridge University Press, 1970.

Sakel, D., "Three Talesfor Sultan? Three Tales on Mehmedt he Conqueror and Patriarch Gennadius", British Jounal of Middle Eastern Studies, 35/2 (Aug. 2008): 227-238.

Seyfeli, Canan, “İstanbul Ermeni Patrikhanesi”, TDV Íslam Ansiklopedisi. 16: 668-671. Ankara: Türkiye Diyanet Vakfı Yayınları, 2016. 
Seyfeli, Canan, İstanbul Ermeni Patrikliği, İstanbul: Çizgi Kitapevi Yayınları, 2019.

Steinscheneider, M. Polemische und apologetische Literatur in arabis- cher Sprachezwischen Muslimen, ChristenundJuden. Leipzig: yy, 1877.

Thomas, David. "Hujjaj al-milla l-Hanafiyye ve cewab kull sual”. 5:419-420. Christian Muslim A Bibliographical History (1350-1500), Leiden-Boston: Brill, 2013.

Todt, Klaus-Peter, “Gennadius II Scholaris”, 5:503-518. Christian Muslim A Bibliographical History (1350-1500), Leiden-Boston: Brill, 2013.

Turner, C. J. G. "The Career of George-Gennadius Scholaris". Byzantion, 39 (1969): 420-55.

Uegaki, Tomoo. Byzantine Religious Dialogues with Muslims in the Fourteenth and Fifteenth Centuries. MA thesis, University of Birmingham, 2015.

Yıldız, Yusuf. Papa PiusII'un Fatih Sultan Mehmet'e Mektubu. Akçağ Yayınları, 2018.

Ziaka, Angeliki. "Rearticulating a Christian-MuslimUnderstanding: GennadiosScholarios and George Amiroutzes on Islam”. Studies in ChurchHistory, 51 (2015):154-55, 161-3.

Ziaka, Aristeides. Papdakis, “Gennadius II and Mehmed II the Conqueror”. Byzantion, 1972, vol. 42/1 (1972): 91, 94. 
